\title{
Diet, Stress and Mental Health
}

\author{
J. Douglas Bremner ${ }^{1,2,3, *}{ }^{\mathbb{C}}$, Kasra Moazzami ${ }^{4,5}$, Matthew T. Wittbrodt ${ }^{1}{ }^{\complement}$, Jonathon A. Nye ${ }^{2}$, \\ Bruno B. Lima ${ }^{4,5}$, Charles F. Gillespie ${ }^{1}$, Mark H. Rapaport ${ }^{1}$, Bradley D. Pearce ${ }^{5}$, \\ Amit J. Shah ${ }^{3,4,5}$ and Viola Vaccarino ${ }^{4,5}$ \\ 1 Departments of Psychiatry \& Behavioral Sciences, Emory University School of Medicine, \\ Atlanta, GA 30329, USA; mwittbr@emory.edu (M.T.W.); cgilles@emory.edu (C.F.G.); \\ mark.h.rapaport@emory.edu (M.H.R.) \\ 2 Department of Radiology, Emory University School of Medicine, Atlanta, GA 30332, USA; jnye@emory.edu \\ 3 Atlanta VA Medical Center, Decatur, GA 30033, USA; ajshah3@emory.edu \\ 4 Department of Medicine (Cardiology), Emory University School of Medicine, Atlanta, GA 30332, USA; \\ kmoazza@emory.edu (K.M.); bruno.bezerra.lima@emory.edu (B.B.L.); lvaccar@emory.edu (V.V.) \\ 5 Department of Epidemiology, Rollins School of Public Health, Emory University, Atlanta, GA 30322, USA; \\ bpearce@emory.edu \\ * Correspondence: jdbremn@emory.edu
}

Received: 17 June 2020; Accepted: 4 August 2020; Published: 13 August 2020

\begin{abstract}
Introduction: There has long been an interest in the effects of diet on mental health, and the interaction of the two with stress; however, the nature of these relationships is not well understood. Although associations between diet, obesity and the related metabolic syndrome (MetS), stress, and mental disorders exist, causal pathways have not been established. Methods: We reviewed the literature on the relationship between diet, stress, obesity and psychiatric disorders related to stress. Results: Diet and obesity can affect mood through direct effects, or stress-related mental disorders could lead to changes in diet habits that affect weight. Alternatively, common factors such as stress or predisposition could lead to both obesity and stress-related mental disorders, such as depression and posttraumatic stress disorder (PTSD). Specific aspects of diet can lead to acute changes in mood as well as stimulate inflammation, which has led to efforts to assess polyunsaturated fats (PUFA) as a treatment for depression. Bidirectional relationships between these different factors are also likely. Finally, there has been increased attention recently on the relationship between the gut and the brain, with the realization that the gut microbiome has an influence on brain function and probably also mood and behavior, introducing another way diet can influence mental health and disorders. Brain areas and neurotransmitters and neuropeptides that are involved in both mood and appetite likely play a role in mediating this relationship. Conclusions: Understanding the relationship between diet, stress and mood and behavior could have important implications for the treatment of both stress-related mental disorders and obesity.
\end{abstract}

Keywords: obesity; metabolic syndrome; serotonin; ghrelin; galanin; somatostatin; microbiome; brain; stress disorders; posttraumatic; child abuse; depressive disorder; diet; nutrition; cardiovascular disease; myocardial ischemia; coronary artery disease; Mediterranean diet

\section{Introduction}

The relationship between diet and behavior has long been a topic of interest. This includes the effects of diet on both mental and physical health, as well as related topics of the role of stress and obesity in these processes [1]. Dietary modification can prevent the development of cardiovascular disease (CVD) and diabetes [2], and stress-related mental disorders, including major depression and posttraumatic stress disorder (PTSD), are associated with an increased risk for CVD [3-8], although 
the mechanisms of these interactions are not well understood $[9,10]$. Specifically, there is a limited understanding of how diet affects mental health, and the way outcomes of unhealthy diet such as obesity interact with stress-related psychiatric disorders.

The relationship between these factors is often bidirectional. For example, changes in diet may influence psychiatric disorders through direct effects on mood, while the development of psychiatric disorders can lead to changes in eating habits [11]. Figure 1 shows the myriad and complex relationships that can exist between diet and psychiatric symptoms. In Path A in the figure, stress can act through the brain to cause an increase in over-eating [12], including binge-eating [13], and a reduction in exercise that in turn leads to obesity and/or metabolic syndrome (MetS, defined as increased blood pressure, and blood sugar, excess waist body fat and elevated cholesterol or triglyceride levels), which may in turn lead to disorders such as depression due to functional and/or social impairments [14]. In Path B, stress-related psychiatric disorders develop (PTSD, depression) that are associated with changes in metabolism and obesity [15]. Path C acts through physical disorders such as cardiovascular disease (CVD) and diabetes, that may come by way of PTSD and depression, and are related to those disorders in a bidirectional relationship or perhaps through shared pathways. Stress-induced over-eating leads to obesity, which in turn can be associated with changes in neurotransmitters, neuropeptides, and inflammatory factors that are present in both the gut and the brain and have effects on both mood and subsequent eating behaviors [16,17]. Path D shows the effects of neurotransmitters (e.g., serotonin) and neurohormones (cortisol), inflammatory factors are shown in Path E, and neuropeptides (ghrelin, galanin) reviewed below are shown in Path F. Finally, returning to Path A, changes in diet can affect the gut microbiome, which can have effects on mood, and is involved in a complicated bidirectional interaction between brain and inflammatory function as well as the abovementioned neurotransmitters and neuropeptides [18].

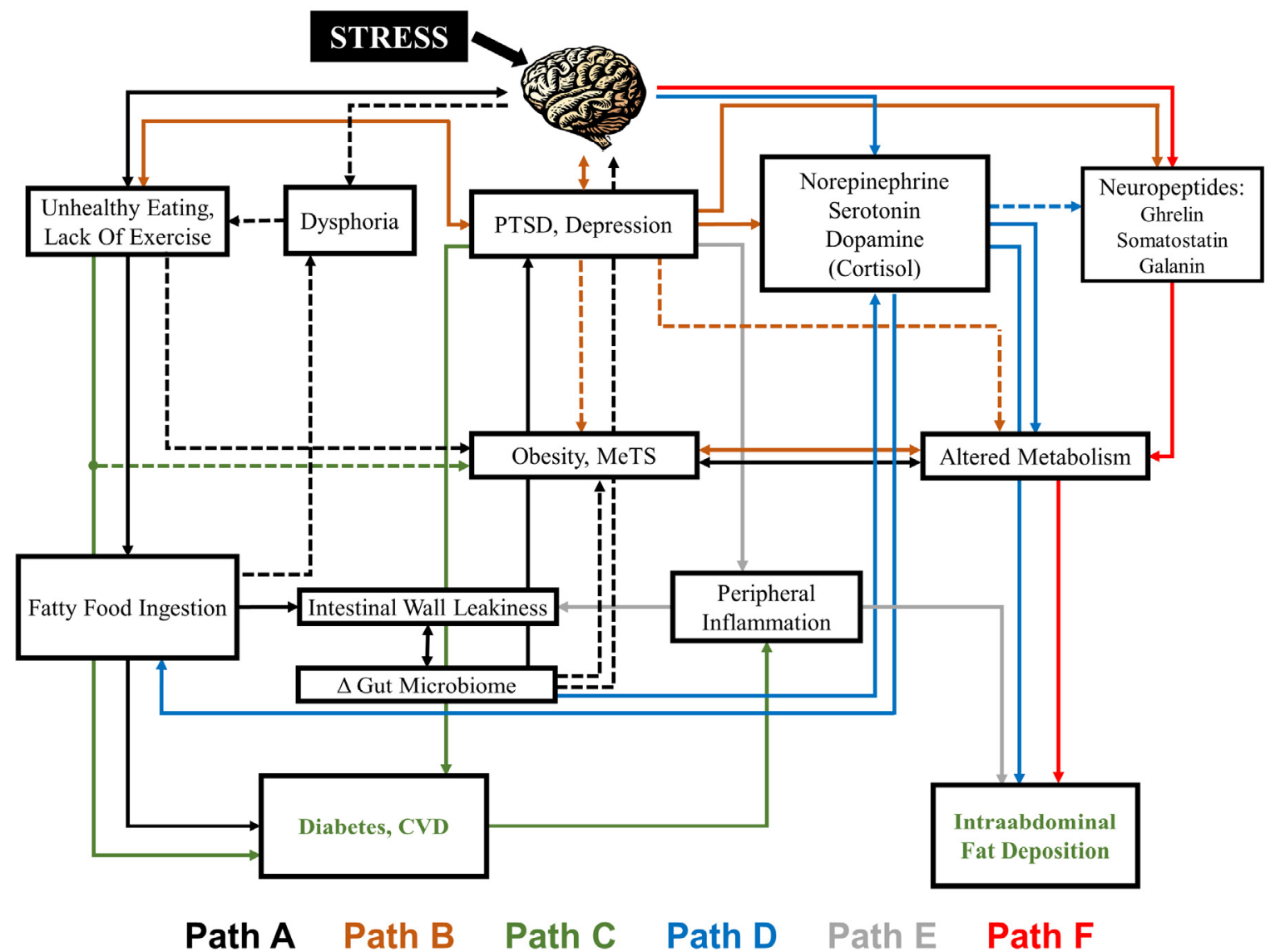

Figure 1. The complex relationship between diet, obesity and behavior. Stress acts through the brain to both affect eating and exercise behaviors (Path A) and stress-related psychiatric disorders including 
posttraumatic stress disorder (PTSD) and depression (Path B), both of which can lead to changes in metabolism, metabolic syndrome (MetS) and obesity (Paths A and B). Binary relationships also exist between unhealthy eating and PTSD/depression and the brain (i.e., both in turn lead to changes in brain function). Unhealthy eating can result in diets high in saturated fat (fatty food ingestion) (Path A) that can affect mood (dysphoria) as well as leakiness of the intestinal wall (Path A), which can lead to changes in the gut microbiome which modulate obesity, MetS and metabolism (Path A), as well as feeding back on the brain (Path A) to influence mood (dysphoria). Physical disorders including cardiovascular disease (CVD) and diabetes (Path C) and physical factors such as intra-abdominal fat (Path C) are affected by stress and related to PTSD and depression. A complex system of neurotransmitters (norepinephrine, serotonin, dopamine) (Path D), inflammatory markers (Path E) and neuropeptides (ghrelin, somatostatin, galanin) (Path F) present in the gut and brain are also influenced by stress via the brain, influence the gut microbiota and physical disorders and factors in a binary fashion and in turn regulate both feeding behavior and psychiatric disorders. Within the figure, the line color indicates the path, with dashed lines indicating primary pathways and solid lines indicating secondary pathways.

This paper reviews possible mechanisms by which diet and obesity can affect mental health and the brain, and the complex interplay between these different factors. We review the effects of diet on mood, with feelings of dysphoria or symptoms of depression most relevant within this context. Factors such as ingestion of fatty foods, as reviewed below, may impact feelings of dysphoria, which is relevant to the topic. Many studies reviewed below examined depressive symptoms in populations that are not suffering from psychiatric disorders, such as pregnant women, or looked at populations such as the elderly in the community at risk for nutritional deficiencies. These studies of depressive symptoms are to be differentiated from studies of populations that meet the criteria for major depression, which together with PTSD are more relevant to the practice of clinical psychiatry. Another relevant topic to effects of diet on mental health is the area of supplements and specific food products, including polyunsaturated fats (PUFAs), which have been the subject of a variety of clinical trials as both treatments and preventative agents for depression.

\section{Materials and Methods}

The literature was reviewed from 1980 through June of 2019 using PubMed and Psych info with keywords diet; obesity; stress disorders; posttraumatic; stress; depressive disorders; depression; inflammation; and polyunsaturated fatty acids. Relevant articles were reviewed and included here. We included both cross-sectional studies and cohorts (retrospective and prospective) that investigated the effects of diet on mood, including depression and dysphoria. This review focused on stress-related psychiatric disorders including major depression and PTSD, as defined in the Diagnostic and Statistical Manual (DSM-5) [19]. These are not the only two psychiatric disorders influenced by stress, of course, but they have been the focus of the bulk of the research on diet and stress, and related topics such as obesity and metabolism. Mental disorders are considered synonymous with psychiatric disorders, and, for the purposes of this review, refer to PTSD and depression, which are also referred to as stress-related psychiatric conditions or mental disorders, and mental health is considered as the absence of these conditions, again for the purposes of this review. Mood entails changes in emotions including depressed or sad emotions, or depressive symptoms, which may or may not be related to the DSM-5 diagnosis of major depression, but is referred to here as relevant to understanding the effects of stress and diet on behavior.

\subsection{Effects of Diet on Health}

In the past forty years, there has been a remarkable increase in worldwide obesity [20,21], which has been associated with an increase in type-2 diabetes and cardiovascular disease [22,23]. The increase in obesity is likely secondary to an expansion of the Western diet, which includes higher amounts of omega- 6 relative to omega- 3 fatty acids relative to other diets, largely through the substitution of 
carbohydrates in the form of grains for leafy plants, represented by ubiquitous processed foods [24]. Factors including an increase in perceived stress and a shift in the labor force from manual labor to sedentary occupations have also likely contributed to overeating (including binge eating) and the growth in obesity [2,25]. After a long period of no change, the prevalence of obesity in the United States doubled every decade in the 1980s and 1990s, and now one third of Americans are afflicted by obesity and another one third overweight [26]. Obesity is associated with a $44 \%$ increase in risk for myocardial infarction, with an even more important association with abdominal fat that further contributes to systemic inflammation [27,28]. From 2000 to 2010, the prevalence of type-2 diabetes increased by $46 \%$, from 151 million to 221 million world-wide [29], with more recent estimates showing 442 million persons to be affected by type 1 and type 2 diabetes worldwide [30], an effect largely driven by obesity [31-34]. Ethnic Chinese who emigrated from their homes in China, where the prevalence of diabetes was $2 \%$, to countries where Western diets were more prevalent, such as Mauritius, experienced an increase in diabetes prevalence to 15\% [29]. Modification of diet can reduce risk of diabetes [35] and cardiovascular disease [36].

One dietary approach that has been particularly well researched is the Mediterranean diet. This diet is rich in nuts, vegetables and fruit, and low in meat, with moderate consumption of red wine, and substitutes of unsaturated fats (olive oil) for saturated and monounsaturated fats (butter, animal fat). Originally described in Italians living in the countryside, the diet was noted to be associated with long life spans and low rates of cardiovascular disease. Studies have confirmed that the Mediterranean diet is associated with sustained weight loss [37], with a beneficial effect on cardiac autonomic function, reductions in peripheral inflammation, and reduced rates of cardiovascular disease, stroke, cancer, and mortality [1,37-41]. The beneficial effects of diet on health have led to speculation that diet modification may be beneficial for symptoms of depression.

\subsection{The Influence of Diet on Mood and Psychiatric Disorders}

The relationship between diet and mental disorders is complex. Studies have shown an increase in depression in obese individuals $[14,42,43]$ that is greater in the presence of MetS [14]. As outlined above, stress can lead to an increase in overeating [16,44-46], obesity [12,47-50] and psychiatric disorders, including PTSD and depression [15]. Depression in obese individuals may be due to psychological issues related to self-consciousness about appearance, common factors such as a history of childhood abuse [12,47-50], or factors such as diet-induced changes in the gastrointestinal microbiome with effects on the brain [51,52]. Early trauma associated with obesity in adulthood is likely due to a resetting of metabolism, independent of changes in eating habits related to dysphoria and other emotional disturbances [12,53]. Binary relationships also exist between these variables as well; for instance, stress causes changes in eating habits, leading to obesity and MetS, which in turn can exacerbate depression.

Diet can also have direct effects on mood. The effect of diet on brain function is one pathway through which diet can affect mood and the development of psychiatric disorders [42-45]. Fats are known to interfere with the synthesis of serotonin, a key brain neurotransmitter implicated in the development of depression, while proteins have the opposite effect [42]. Therefore, a high fat diet has been hypothesized to cause mood disorders (while a low-fat diet would have the opposite effect) [54]. Research studies have in fact shown that high fat foods can lead to transient changes in mood [55], possibly via signaling of gut flora that is perceived by the brain [45]. Intake of fats leads to feelings of sleepiness that are not related to the food alone [56,57]. Uncontrolled observational studies have shown a reduction in fats in the diet in depressed patients who have a resolution of depression [58] and a relationship between symptoms of anxiety and depression, and a low carbohydrate, high fat diet [59]. Survey studies showed that patients consuming a diet similar to the Mediterranean diet had a reduced risk for the development of depression [60]. In summary, the relationship between diet, stress and psychiatric disorders is complex and likely bidirectional, with diet affecting psychiatric symptoms and psychiatric symptoms affecting diet with interactions with stress and obesity. 
Studies in populations without the diagnosis of depression on the effects of dietary interventions have been mixed $[11,61]$. Although some studies showed a reduction in depressive symptoms in healthy insurance company employees with a vegan diet [62], elderly persons at risk for malnutrition [63,64], and women with breast cancer [65] with nutritional interventions and/or diets, other studies in healthy subjects showed no effects of a low carbohydrate high fat compared to a high carbohydrate low fat diet [66] or a low-fat diet versus no intervention [67]. Studies of dietary interventions with and without exercise training aimed at weight loss for obese and overweight individuals have in general shown improvements in well-being and quality of life without clinically significant reductions in symptoms of depression [68-71]. Similarly, studies of the Mediterranean diet did not show a reduction in symptoms of depression in populations without the clinical diagnoses of depression, although there were improvements in factors such as quality of life or self-reported vigor in some studies [72-77].

Studies have looked at the effects of dietary interventions in patients with depression. Two studies included veterans identified as having some symptoms of depression and exposure to psychological trauma who were randomized to a diet education group or problem-solving therapy (PST). In one sample, treatment with PST was associated with greater improvement in mental health as measured with the SF-36 with no difference between groups in depressive symptoms measured with the Beck depression inventory (BDI) [78]. A second study with a similar sample failed to find an improvement in depression with diet training [79]. The Supporting the Modification of lifestyle in Lowered Emotional States (SMILES) trial was performed in patients with clinical depression. In this study, a modified Mediterranean Diet intervention was associated with improvement in depression as measured with the Montgomery Asberg Depression Rating Scale (MADRAS) compared with a social support intervention which matched the number and length of visits [80].

In addition to depression, recent studies suggested a relationship between sleep duration and Mediterranean Diet. In the MESA Sleep ancillary study, a higher adherence to a Mediterranean-type diet was associated with a $43 \%$ greater likelihood of achieving $6-7 \mathrm{~h}$ of sleep per night compared to $6 \mathrm{~h}$ [81]. Data from the Seniors-ENRICA and Hellenic Longitudinal studies also found a lower likelihood of poor sleep quality for those who were following a Mediterranean diet $[82,83]$. Finally, a study performed in France showed that adherence to a Mediterranean diet predicted reduced risk of insomnia [84].

In summary, there is not strong evidence for an effect of dietary intervention on symptoms of depression, although effects are possible in patients with the clinical diagnosis of depression.

\subsection{Diet Interventions for Depression}

The use of dietary supplements for the treatment of depression has been the subject of intensive investigation [11] (Table 1). Omega-3 polyunsaturated fatty acids (n-3 PUFAs) are highly concentrated in fish oil, especially from mackerel, salmon, herring and sardines. (n-3 PUFAs)contain more double carbon bonds than saturated fats, such as butter and animal fats, and are more likely to be solid than liquid at room temperature. n-3 PUFAs, including eicosapentaenoic acid (EPA) and docosahexaenoic acid (DHA), have beneficial effects on health, including reduction in cardiovascular disease risk, improved cognition, enhancement of neuroplasticity, and protection against neuronal injury [85-89]. n-3 PUFAs are included in the category of eicosanoids, which bind to intra-nuclear receptors and regulate gene transcription, making them part of the nuclear receptor superfamily, which includes steroids, thyroid hormone, and retinoids, all of which have been linked to neuropsychiatric syndromes [90]. These studies suggested that n-3 PUFAs may have benefit in the treatment and/or prevention of depression. 
Table 1. Controlled Trials on Dietary Interventions for Depression.

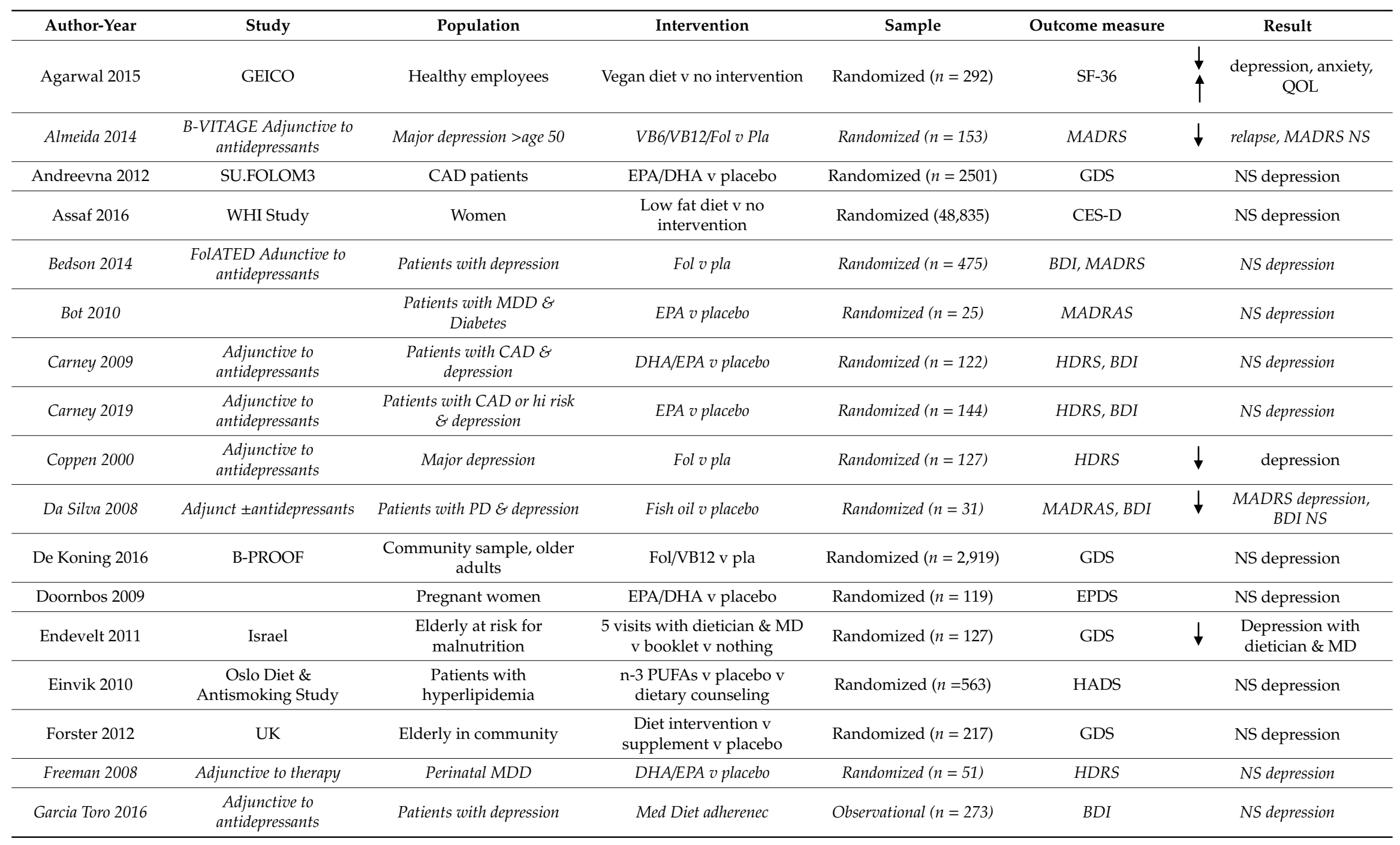


Table 1. Cont.

\begin{tabular}{|c|c|c|c|c|c|c|}
\hline Author-Year & Study & Population & Intervention & Sample & Outcome measure & Result \\
\hline Gharekhani 2014 & & $\begin{array}{l}\text { Hemodialysis patients with } \\
\text { depressive symptoms }\end{array}$ & DHA/EPA v placebo & Randomized $(n=54)$ & BDI & Depression \\
\hline Gertsik 2012 & $\begin{array}{l}\text { Adjunctive to } \\
\text { antidepressants }\end{array}$ & Patients with depression & $\begin{array}{c}\text { Citalopram }+ \\
\text { EPA/DHA/O3FA v Cit + pla }\end{array}$ & Randomized $(n=46)$ & HDRS & depression \\
\hline Grenyer 2007 & $\begin{array}{l} \pm \text { Adjunctive to } \\
\text { antidepressants }\end{array}$ & Patients with depression & DHA/EPA (fish oil) v placebo & Randomized ( $n=83$ ) & $H D R S, B D I$ & NS depression \\
\hline Halyburton 2007 & & $\begin{array}{l}\text { Overweight or Obese } \\
\text { patients }\end{array}$ & $\begin{array}{l}\text { Low carb high fat } v \text { high } \\
\text { carb low fat diet }\end{array}$ & Randomized $(n=93)$ & POMS, BDI & $\begin{array}{c}\text { Weight in both groups, } \\
\begin{array}{c}\text { cognition low fat, NS } \\
\text { depression }\end{array}\end{array}$ \\
\hline Нyyра 2003 & & $\begin{array}{l}\text { Men with hyper- } \\
\text { cholesterolemia }\end{array}$ & $\begin{array}{l}\text { Simvistatin v Med Diet v } \\
\text { placebo }\end{array}$ & Randomized $(n=120)$ & BSI & NS depression \\
\hline Imayama 2011 & & $\begin{array}{l}\text { Obese and overweight } \\
\text { post-menopausal women }\end{array}$ & $\begin{array}{l}\text { Weight loss diet, exercise v } \\
\text { no intervention }\end{array}$ & Randomized ( $n=439$ ) & BSI & $\downarrow \quad \begin{array}{c}\text { Depression } \\
\text { diet/exercise, NS } \\
\text { depression diet alone }\end{array}$ \\
\hline Jacka 2017 & SMILES study & $\begin{array}{l}\text { Patients with clinical } \\
\text { depression }\end{array}$ & Med. Diet v Social Support & Randomized $(n=67)$ & MADRAS & Depression \\
\hline Jazayeri 2008 & & $\begin{array}{l}\text { Patients with clinical } \\
\text { depression }\end{array}$ & $\begin{array}{c}F l u+E P A v f l u+p l a v E P A+ \\
p l a\end{array}$ & Randomized $(n=60)$ & HDRS & Depression \\
\hline Kasckow 2014 & & $\begin{array}{c}\text { Veterans with symptoms of } \\
\text { depression }\end{array}$ & Diet Education Group v PST & Randomized $(n=45)$ & BDI, SF-36 & $\begin{array}{l}\text { NS depression, } \\
\text { GMH }\end{array}$ \\
\hline Kasckow 2014 & & $\begin{array}{c}\text { Veterans with symptoms of } \\
\text { depression }\end{array}$ & Diet Education Group v PST & Randomized $(n=60)$ & BDI & NS depression \\
\hline Kwok 2019 & & Older MCI+ H-Hcy & VB12/fol v pla & Randomized $(n=279)$ & CDR, HDRS & Depression \\
\hline Llorente 2003 & & $\begin{array}{l}\text { Obese and overweight } \\
\text { post-menopausal women }\end{array}$ & DHA v placebo & Randomized $(n=439)$ & BSI & NS depression \\
\hline Lesperance 2011 & & Patients with depression & EPA/DHA v placebo & Randomized $(n=432)$ & IDS & NS depression \\
\hline Llorente 2003 & & Pregnant women & DHA v pla & Randomized $(n=99)$ & BDI & \\
\hline Lucas 2009 & & $\begin{array}{l}\text { Middle aged women with } \\
\text { symptoms of depression }\end{array}$ & EPA/DHA v pla & Randomized $(n=120)$ & HDRS & NS depression \\
\hline Makrides 2010 & DOMInO study & Pregnant women & DHA v pla & Randomized $(n=2399)$ & EPDS & NS depression \\
\hline
\end{tabular}


Table 1. Cont.

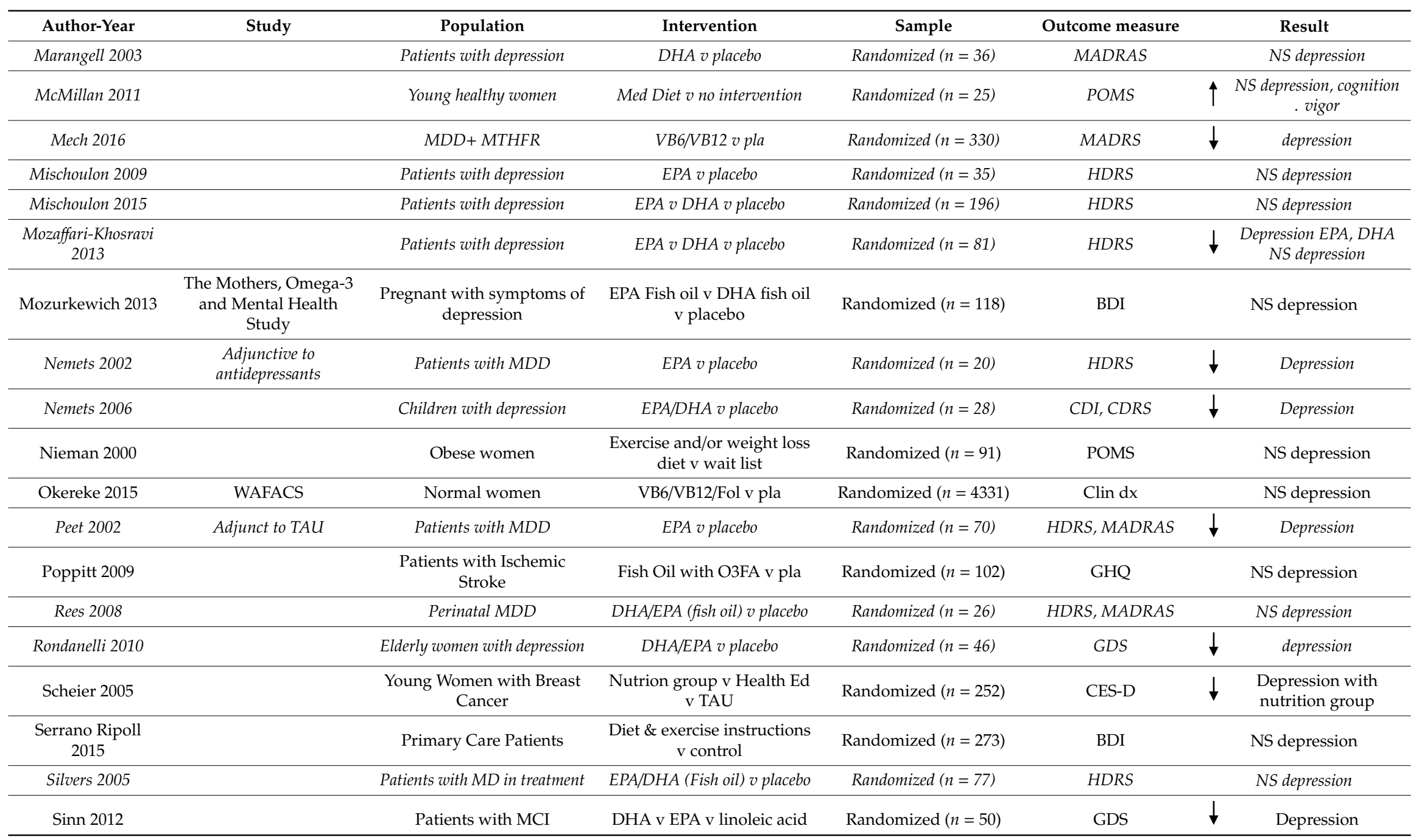


Table 1. Cont.

\begin{tabular}{|c|c|c|c|c|c|c|}
\hline Author-Year & Study & Population & Intervention & Sample & Outcome measure & Result \\
\hline Stoll 1999 & & Patients with Bipolar Disorder & EPA/DHA (Fish oil) v placebo & Randomized $(n=30)$ & $\begin{array}{l}\text { Time to relapse } \\
\text { (clinical) }\end{array}$ & Delayed relapse \\
\hline Su 2003 & Adjunct to TAU & $M D D$ & EPA/DHA v placebo & Randomized $(n=28)$ & HDRS & depression \\
\hline Su 2008 & & Pregnant women with MDD & EPA/DHA v placebo & Randomized $(n=36)$ & HDRS & depression \\
\hline Su 2014 & & Interferon patients & DHA or EPA v placebo & Randomized $(n=162)$ & Mini & Depression onset \\
\hline $\begin{array}{c}\text { Tajalizadekhoob } \\
2011\end{array}$ & Adjunct to TAU & $\begin{array}{c}\text { Elderly with mild to mod } \\
\text { depression }\end{array}$ & EPA/DHA (Fish oil) v placebo & Randomized $(n=66)$ & GDS & depression \\
\hline Tayama 2019 & & $\begin{array}{c}\text { Patients with mild to mod } \\
\text { depression }\end{array}$ & EPA/DHA v placebo & Randomized $(n=90)$ & $B D I$ & NS depression \\
\hline Toobert 2007 & Med Lifestyle Program & $\begin{array}{l}\text { Postmenopausal women } \\
\text { with DM2 }\end{array}$ & $\begin{array}{l}\text { Med Diet \& exercise v } \\
\text { control }\end{array}$ & Randomized $(n=279)$ & CES-D & NS depression or QOL \\
\hline Wardle 2000 & & $\begin{array}{l}\text { Patients with hyper- } \\
\text { cholesterolemia }\end{array}$ & $\begin{array}{c}\text { Low fat } \mathrm{v} \text { Med Diet } \mathrm{v} \text { wait } \\
\text { list }\end{array}$ & Randomized $(n=176)$ & BDI, POMS & NS depression \\
\hline
\end{tabular}

Controlled trials of the effects of diet and/or diet education on symptoms of depression. Studies in italics include trials of patients with clinical depression. BDI = Beck Depression Inventory; BSI = Brief Symptom Inventory; $\mathrm{CAD}=$ Coronary Artery Disease; $\mathrm{CDI}=$ Children's Depression Inventory; Clin $\mathrm{dx}=$ clinician diagnosis of depression; $\mathrm{CRD}=\mathrm{Clinical}$ Dementia Rating Scale; CDRS=Children's Depression Rating Scale; CES-D = Center for Epidemiological Studies-Depression Scale; Cit = citalopram; DM2 = Type 2 Diabetes Mellitus; DOMInO=DHA

to Optimize Mother Infant Outcome trial; EDPS = Edinburgh Postpartum Depression Scale; Flu = fluoxetine; Fol = Folate; GDS=Geriatric Depression Scale; GHQ = General Health Questionnaire; GMH = General Mental Health; HADS = Hospital Anxiety and Depression Scale; Hcy = homocysteine; H-Hcy = hyperhomocysteinemia; HDRS = Hamilton Depression Rating Scale; IDS = Inventory of Depressive Symptomatology; n-3 PUFAs = n-3 polyunsaturated fatty acids; MADRAS = Montgomery Asberg Depression Rating Scale; MCI = Mild Cognitive Impairment; MDD = Major Depression Disorder; Med Diet = Mediterranean Diet; Mini = Mini International Psychiatric Interview; MTHFR = methylenetetrahydrofolate reductase plymorphism; NS = non significant (no difference between study groups); O3FA = Omega-3 Fatty Acids; Pla = Placebo; POMS = Profile of Mood States; PST = Problem Solving Therapy; Rem = remission of depressive symptoms; SF-36 = Short Form 36 Items (Quality of Life (QOL), depression, anxiety); SMILES = Supporting the Modification of Lifestyles in Lowered Emotional States (trial); TAU = Treatment as Usual; VB12 = Vitamin B-12; $\downarrow$ = decrease; $\uparrow=$ increase; VB6 = Vitamin B-6WHI = Women's Health Initiative. 
Patients with depression have an increase in inflammation [91-93] and n-3 PUFAs have an inhibitory effect on this system, which suggests another potential beneficial effect for this disorder [94]. Inflammasomes are multi-protein complexes that detect signals in the inflammation pathway and activate pro-inflammatory cytokines [95]. Danger-associated molecular patterns (DAMPs) induced by stress are recognized by pattern-recognition receptors (PRRs), which trigger production of interferon alpha and beta and pro-inflammatory cytokines. Families of PRRs that are components of the inflammasome complex include nucleotide-binding domain, leucine-rich repeat containing proteins (NLRs, or NOD-like receptors). These induce caspase-1 and the inflammatory response and play a role in diseases involving inflammation [96], including PTSD and depression [92,97]. Specialized proresolving mediators (SPMs), including resolvins, lipoxins, maresins, and protectins, act as brakes on the inflammatory response and are released at the time of the initial inflammatory response [98-100]. Resolvins D1 and D2, derived from DHA, act through the mammalian target of rapamycin complex 1 (mTORC1) in the medial prefrontal cortex and hippocampus to mediate anti-inflammatory and antidepressant effects [101,102]. Similar effects are seen with resolvins E1 and E2, which are derived from EPA [103,104]. Studies showed an increase in the inflammasome NLRP3 and caspase-1 in blood cells of patients with major depression, with associated increases in interleukin $1 \beta$ (IL-1 $\beta$ ) and IL-18, which correlated with depression severity [105]. NLRP12 was also found to be increased in Vietnam veterans with depression and coronary artery disease (CAD) [106]. Other studies showed an increase in myeloperoxidase [107].

Patients with depression also show alterations in endogenous n-3 PUFAs that may be linked to inflammatory alterations in these patients $[11,54]$. Patients with depression had higher blood concentrations of omega- 6 relative to omega- 3 fatty acids compared to individuals without depression [108], and depressed patients with low DHA and an elevated omega-6/omega-3 ratio in blood had an increased risk for suicide [109]. Elevated baseline inflammatory cytokines in patients with major depression predicted both risk for MetS [110] as well as a positive response to PUFA treatment for depression [94]. These studies suggested a complex but potentially relevant relationship between depression, inflammation, and n-3 PUFAs.

Studies have looked at n-3 PUFAs delivered as fish oil or DHA and EPA in comparison to placebo in several at risk non-depressed populations (Table 1). Hemodialysis patients randomized to a combination of DHA and EPA or placebo showed a significant reduction in depressive symptoms as measured with the BDI after four months [111]. EPA, but not DHA, resulted in a significant reduction in the number of patients who developed depression following treatment with interferon alpha for hepatitis C compared to placebo, although both EPA and DHA resulted in a significant delay in the onset of depressive symptoms [112]. DHA and/or EPA has not been found to result in significant decreases in symptoms of depression in patients with a history of ischemic stroke [113], mild cognitive impairment (MCI) [114], hyperlipidemia [115], or CAD [116,117]. Similarly, administration of DHA and/or EPA to pregnant and/or postpartum women did not result in a decrease in symptoms of depression [118-121]

Clinical trials of n-3 PUFAs have been conducted in patients with the diagnosis of depression. Randomized treatment with n-3 PUFAs in the form of fish oil, EPA and/or DHA compared to placebo showed a reduction in symptoms in patients with depression [11,54,92,107,122-138]. Patients with major depression and elevations in inflammatory biomarkers showed a stronger response to EPA (but not DHA) treatment compared to depressed patients without elevations in inflammatory biomarkers [94]. Other studies, however, did not show improvement in patients with depression [127,136,139-145]. Two studies of DHA and/or EPA added to the antidepressant sertraline in patients with depression and CAD or at risk for CAD showed no improvement compared to sertraline plus placebo [146,147]. Overall, studies are suggestive if not definitive, with a pattern of greater effect for EPA, especially when used as an adjunct to antidepressants, and in patients with more severe depression and/or biomarkers such as elevated inflammation. 
Homocysteine is another dietary component that has been studied in relation to depression. Homocysteine is a sulfur-containing amino acid that is involved in carbon transfer reactions and is part of the B-12 and folate metabolic pathway [148]. Homocysteine can receive a methyl group from $5^{\prime}$-methyltetrahydrofolate and become re-methylated to methionine, the immediate precursor of S-adenosylmethionine (SAMe), a donor of methylation reactions involved in the synthesis of DNA, proteins, phospholipids, neurotransmitters and polyamines relevant to depression, including dopamine, norepinephrine and serotonin in the brain. Some studies have shown efficacy for SAMe in the treatment of depression [149].

Elevated homocysteine concentrations can result from folate or B12 deficiency. Several studies have found a relationship between elevated homocysteine levels and/or low folate and B vitamins and depression [150-152]. Diets deficient in folate and vitamins B6 and B12 are also associated with depression [153]. Since the Mediterranean diet is rich in folate and B12, it could possibly reduce the risk of depression through correction of this nutritional deficiency. Consistent with this, adherence to the Mediterranean diet was associated with a reduction in circulating levels of homocysteine [154].

Studies in patients with depression supported a link between elevated homocysteine and low folate and Vitamin B12 and depression. Low baseline folate and vitamin B12 [155] and elevated homocysteine $[155,156]$ predicted subsequent development of depression, and elevated homocysteine correlated with a past history of depression in men (but not women), even after adjusting for health-related behaviors [157]. Low folate (but not low vitamin B12 or elevated homocysteine) has been shown to be a predictor of poor response to antidepressants [158-161], as well as risk of relapse, in patients with depression [159]. Treatment with folate and/or vitamin B12 in patients with elevated homocysteine compared to placebo in healthy older adults resulted in significant decreases in homocysteine [162,163], but no improvement in cognition [162] or symptoms of depression [163,164] (Table 1). Long-term supplementation with folate and vitamin B12 did not prevent the development of depression in healthy women [165]. Studies in patients with depression showed that folate and/or Vitamin B12, including as an augmentation to antidepressants, resulted in improved symptoms of depression in some studies [166-170] but not others [164,171,172]. Greater reductions in depression were seen in depressed patients with the MHTFR polymorphism [167,173]. Supplementation of antidepressants with folate and/or vitamin B12 in one study reduced the risk of relapse after successful remission [172]. Not all studies, however, have found an association between homocysteine and depression [174-179]. The population-based Rotterdam Study found an association between depression and homocysteine; however, the association was reduced after controlling for cardiovascular disease and functional disability [152]. These inconsistent results may be due to factors such as variations in diet and vitamin supplementation, which can affect folate intake, which influences homocysteine concentrations.

The Dietary Inflammatory Index has been developed in recent years to characterize an individual's diet on a continuum from anti- to pro-inflammatory. Numerous studies investigating the role of Dietary Inflammatory Index on depression [180-183]. Results from the Whitehall II Study show a positive association between this index and recurrent depressive symptoms in women but not men [181]. Similar findings were observed in the Australian Longitudinal Study on Women's Health, where women with the highest inflammatory diet had an approximately $20 \%$ higher risk of developing depression compared to those with the lowest pro-inflammatory diet [180]. In another cohort study of 15,093 university graduates, participants in the highest quintile of Dietary Inflammatory Index were found to have a $47 \%$ increased risk of developing future depression compared to those in the lowest quintile [182].

Studies on the relationship between diet and depression have limitations. Many of the studies reviewed above and in Table 1 involve populations without clinical depression and have considerable variability from study to study. Although it can be argued that some of these groups should be the subject of study because of potential risk for the development of depression, such as pregnant women, or patients with stroke, cancer, renal failure, $\mathrm{CAD}$ or $\mathrm{MCI}$, they do not have equivalent relevance to the practice of clinical psychiatry as patients with the current diagnosis of major depression. Overall, 
findings from these studies suggest that although diet and/or supplements such as PUFAs may enhance "vigor" or quality of life, there is limited evidence for the prevention of or reduction in the development of symptomatic depression. Studies that did report positive results in non-clinical samples also had important limitations. For instance, the study of employees of an insurance company (the GEICO study) randomized to a vegan diet versus control used a design where group assignment occurred at company sites rather than on an individual level, so one company site was having regular meetings with dieticians, which were presumably discussed amongst employees, while the other site received nothing. Additionally, the study involved healthy individuals, used a measure not validated as a measure of clinical depression, and was performed by an advocacy group whose mission includes promotion of a plant-based diet [62]. Similarly, in a study of women with breast cancer, a dietary intervention induced a reduction in depression that was related to a one-point mean change in a 30-point scale (CES-D), with no change in mental health function, which although statistically significant, was of questionable clinical significance [65]. Obese patients with knee pain assigned to diet or exercise or no intervention showed a statistically significant improvement in depression measured with the Hospital Anxiety and Depression Scale (HADS). The improvement, however, was less than one point on a 21-point scale, which again was of questionable clinical significance [70]. Another study in obese and overweight post-menopausal women randomized to weight loss diet and/or exercise versus no intervention showed an improvement in depression as measured with the Brief Symptom Inventory (BSI) in the exercise and diet group, but not in the diet alone group [184]. These effects did not reach significance after correction for multiple comparisons, however, and involved a 1.7-point change in the BSI (4\% change from baseline) of questionable clinical significance. EPA, but not DHA, resulted in a significant reduction in the number of patients who developed the diagnosis of depression as measured with the Mini following treatment with interferon alpha for hepatitis C compared to placebo, although both EPA and DHA resulted in a significant delay in the onset of depressive symptoms. Neither resulted in a significant reduction in depression compared to placebo on the Hamilton Depression Rating Scale (HDRS) [112]. Therefore, it can be seen that in non-clinical studies, most failed to show an effect of dietary intervention on depression, and if they did it was of questionable clinical significance. Studies in patients with the clinical diagnoses of depression also suffered from limitations. The Supporting the Modification of lifestyle in Lowered Emotional States (SMILES) trial was performed in patients with clinical depression. A modified Mediterranean diet intervention was associated with improvement in depression, as measured with the MADRAS compared to a social support intervention which matched the number and length of visits [80]. This study was criticized, however, for using recruitment materials implying a belief in the positive effects of diet on depression, including ads that had pictures of men made out of fruits [185]. This criticism is similar to that of the GEICO study, in that a bias for dietary change over medications may have been a confounding factor. In fact, nationalistic or cultural biases need to be considered as well. For example, we organized a conference on Mediterranean diet in conjunction with a Southern European country, who presented us with a giant round of Pecorino Romano cheese courtesy of their government's office for the promotion of national products. Similarly, findings supporting beneficial effects of an Indian diet fell apart after publication in The Lancet, when a site visit to the study location revealed only a few broken electrocardiogram machines in an abandoned building in the jungle and the claim that the original data from the study had been eaten by termites [186]. Even in the absence of financial or cultural bias, opinions run strong on the subject of diet and depression. For instance, a meta-analysis found no significant effect of PUFAs on depression after adjusting for possible publication bias, and concluded that positive effects were limited to small studies [187]. This paper was met with another meta-analysis that strongly disputed these conclusions [131]. There have in fact been a large number of meta-analyses, mostly concluding a positive effect for PUFAs on depression [131-134].

Although specific foods may have short-term effects on mood, overall the findings are equivocal for clinically significant effects of diet on mental health. Evidence for a link between obesity and depression is also inconsistent. Replicated findings in fact show a stronger link for MetS than obesity 
with depression [14,34]. It is questionable whether research on the effects of diet on mental health can be adequately controlled given the high expectancy bias for the effects of diet on mood, the inability to mask the nutrition interventions, and the psychosocial impact of multiple meetings in groups devoted to education about health and diet [185]. Effects of n-3 PUFAs on patients with the clinical diagnosis of depression are stronger. In fact, the American Psychiatric Association now recommends intake of 500 mg of omega-3 fatty acids per day in the diet for patients with depression.

\subsection{Neurotransmitters and Neuropeptides Affected by Diet, Obesity and Psychiatric Disorders Related to Stress}

Alterations in neurotransmitters and neuropeptides that are involved in stress, psychiatric disorders and/or appetite represent a possible mechanism by which stress may increase the risk of obesity and form a link between diet and stress-related psychiatric disorders. Tissues in the brain and the gut are both derived from ectodermal cells in fetal development, and share signaling pathways in common that can provide a link between stress, diet, obesity, and psychiatric disorders, including neurotransmitters (Pathway D in Figure 1) and neuropeptides (Pathway F in Figure 1). Serotonin is a neurotransmitter present in the brain and the gut that regulates a wide variety of relevant behaviors and physiological functions, including the regulation of anxiety, arousal, vigilance, aggression, mood, impulsivity, sleep, and food intake, as well as physical functions including cardiovascular, respiratory, motor output, neuroendocrine secretion, and analgesia [188,189]. Stress is associated with alterations in serotonin function in the medial prefrontal cortex and other brain areas involved in the stress response [190,191] and altered serotonin function is associated with both depression and PTSD [192,193]. Cortisol plays a critical role in stress, is altered in PTSD, and is associated with increased deposition of intraabdominal fat [194]. Norepinephrine release in the brain is an important part of the behavioral response to stress $[195,196]$. The majority of norepinephrine cell bodies are located in the brain stem, in the locus coeruleus region of the pons, with axons that extend throughout the rest of the brain, and are activated by stress, leading to fear and anxiety behaviors [197-204]. Alterations in noradrenergic and peripheral sympathetic function play a role in the maintenance of symptoms of both depression and PTSD [193,195,196,205,206]. Norepinephrine also plays an important role in feeding behavior [207]. Dopamine is a neurotransmitter that is involved in a number of functions including the control of locomotion, cognition, affect, neuroendocrine secretion, reward systems including feeding behavior, and the stress response [208-210]. Dopaminergic innervation of the nucleus accumbens, the mesolimbic pathway, regulates feelings of pleasure, and deficits in this system could underlie feelings of a lack of pleasure or anhedonia in patients with stress-related psychiatric disorders [210]. Mesolimbic dopamine also underlies the rewarding properties of food and drives food seeking behaviors, although additional brain regions are also involved in this process [208].

Neuropeptides are another potential link between stress, diet and psychiatric disorders. Somatostatin is the major inhibitor of growth hormone $(\mathrm{GH})$ secretion in the brain and is located in the paraventricular nucleus (PVN) of the hypothalamus, the amygdala, hippocampus, cerebral cortex, median preoptic area, nucleus accumbens, and other areas of the brain [211]. Somatostatin inhibits extinction, modulates sleep, food intake, locomotor activity, and memory function [212] and increases in response to stress [213]. Increased somatostatin levels in the CSF were seen in patients with PTSD [214]. Galanin is a peptide concentrated in brain areas involved in the stress response that mediates a number of physiological and behavioral functions, including learning and cognition, pain control, food intake, neuroendocrine control, and cardiovascular regulation, as well as depression and anxiety $[215,216]$. Alterations in galanin have been hypothesized to underlie depression $[215,216]$. Ghrelin is a peptide synthesized in the stomach and pancreas that is involved in the regulation of appetite and food digestion. Ghrelin levels rise before meals and stimulate food intake, and alterations in ghrelin function have been linked to obesity [217]. Stress increases ghrelin levels in the plasma [218,219], and ghrelin mediates the stress-induced increase in food intake associated with exposure to chronic stress [220] as well as behavioral responses to stress [219]. Ghrelin crosses the blood-brain barrier, where it acts through ghrelin receptors to stimulate the release of growth hormone in the basolateral nuclear of the 
hypothalamus and the amygdala, where it enhances fear learning with chronic stress [221]. In summary, a number of neurotransmitters and neuropeptides that are located in both the brain and the gut and that mediate both stress and feeding behaviors may be the link between stress, diet and stress-related mental disorders.

\subsection{The Gut-Brain Connection}

Recently, the role of the gastrointestinal microbiome in affecting brain function has been recognized, with possible implications for the development of mental disorders in the context of diet and metabolism [18,52]. The gastrointestinal flora is composed of a range of bacterial species that have beneficial effects for our digestion and other functions; these are also affected by factors such as stress and a high fat diet [222-224] and influence brain function through the release of various signaling molecules. Additionally, they interact with neurotransmitters and neuropeptides reviewed in the prior section, which can lead to changes in mood and stress reactivity [45,224-227]. High fat diets can lead to leakiness of the gut epithelium, resulting in the release of inflammatory factors and penetration of gut flora in the intestinal wall, which can further increase the risk of depression via alterations in signaling pathways leading to the brain $[51,227,228]$. Studies have shown that the gut biota can influence both risk for MetS, and via gut biota that synthesize a metabolite of dopamine risk for depression [229,230]. Studies have looked at the effects of the replacement of the bacterial flora with probiotics or other agents for the treatment of mood disorders, with some success [229,231]. In conclusion, the gut microbiome interacts with diet and the environment to affect mental disorders in complex ways that are imperfectly understood but represent a promising area for future research and possible interventions.

\section{Conclusions}

The relationship between diet, obesity, stress, and stress-related psychiatric disorders is complex. Overall, there appears to be a link between diets low in saturated fats and high in omega-3 polyunsaturated fats and reduced risk of both obesity, MetS and stress-related psychiatric disorders, as well as beneficial effects for other health outcomes. This favors a diet that is rich in fruits, nuts, and vegetables, and fish, as is seen in the Mediterranean diet. Specifically, fish oils are a rich source of omega-3 fatty acids, and likely have a beneficial effect on mental and physical health. There are a number of potentially confounding factors, however, such as increased healthy behaviors in those who adhere to specific diets that could contribute to a spurious association. Most studies have focused on dietary interventions such as fish oils or PUFAs in the treatment of depression or the prevention of symptoms of depression in at risk groups. There is not good evidence for dietary interventions for at risk groups, and given the enthusiasm for diet as an intervention, the possibility of confirmation bias cannot be ruled out.

Although a Mediterranean diet, in combination with other behavioral changes, was found to have beneficial effects on perceived stress and well-being, it has not been shown to specifically benefit depression. Some elements of the Mediterranean diet, such as omega-3 fatty acids (found in fish), have been found to be beneficial in some clinical trials. Meanwhile, the addition of folate to the diet (with reduction in homocysteine) is associated with decreased symptoms of depression. In countries such as the United States, folate is added to flour, so depression-related folate deficiency is no longer an issue clinically, although not all countries incorporate the addition of folate to food. Thus, clinicians are likely to continue to advocate for adherence to the Mediterranean diet or diets low in fat and high in n-3 PUFAs as part of a general program of health-promoting behaviors, including exercise. It cannot be assumed, however, that supplements like EPA and DHA will confer the same advantages as consumption of fish, whose dietary compilation they are designed to emulate.

The relationship between high saturated fat diets and mental disorders is more complex. It appears that intake of fat may have an acute effect on mood, leading to symptoms of anxiety and depression. In addition, resolution of depression was associated with a reduction in fat intake in some studies, although it is not clear if the reduction in fat led to resolution of depression, or whether resolution 
of depression led to improved eating habits. Finally, a healthy diet with reduction in obesity will likely have beneficial effects on mental health through improved feelings of wellness and self-esteem, in addition to the known association between obesity and depression. Observational studies of the effects of diet for weight loss and dietary interventions on depression and anxiety have had mixed results, and it is not clear if the science supports clear recommendations for dietary interventions, apart from the "does no harm" approach. Studies with the greatest effect were those where diet was paired with exercise training, which is significant since studies showed benefits of aerobic exercise equivalent to antidepressants for the treatment of clinical depression [232]. The strongest evidence for a role of diet intervention for depression was in the area of PUFA supplements, specifically higher doses of EPA, for patients with the clinical diagnosis of depression. Since there are essentially no side effects, its use as an adjunct to antidepressants should certainly be considered as part of a treatment armamentarium, although not a substitute for current treatments.

Future studies need to assess the relationship between diet and mental disorders. Future studies should emphasize a multi-disciplinary and integrated approach, the use of epidemiological research methods involving studies in the general population of lifestyles beneficial for health, application of rigorous clinical trial methodology, and promotion of healthy behaviors. Studies of interventions in large communities, including schools, are needed, as well the study of the relationship between diet and health in an international context. Finally, further research in the area of the gut biota, neurotransmitters and neuropeptides, and biological systems in the brain and gut will likely contribute to greater knowledge that can advance treatment for stress-related psychiatric disorders, as well as obesity and MetS.

Author Contributions: J.D.B. and V.V. completed systematic review, J.D.B. wrote initial draft of paper, J.D.B., M.T.W. prepared visualization, J.D.B., K.M., M.T.W., J.A.N., B.B.L., C.F.G., M.H.R., B.D.P., A.J.S., V.V. reviewed and edited the paper. All authors have read and agreed to the published version of the manuscript.

Funding: The work presented in this review was supported by grants from the NIH R01 MH056120, R01 HL088726, K24 MH076955, P01 HL101398, T32 MH067547, K24 HL077506, R01 HL068630, R01 HL109413, K23 HL127251, R01 HL125246, S10 RR16917.

Conflicts of Interest: None of the authors have a relevant financial conflict to disclose.

\section{References}

1. Sofi, F.; Cesari, F.; Abbate, R.; Gensini, G.F.; Casini, A. Adherence to Mediterranean diet and health status: A meta-analysis. BMJ 2008, 337, a1344. [CrossRef] [PubMed]

2. Perk, J.; De Backer, G.; Gohlke, H.; Graham, I.; Reiner, Z.; Verschuren, M.; Albus, C.; Benlian, P.; Boysen, G.; Cifkova, R.; et al. European Guidelines on cardiovascular disease prevention in clinical practice (version 2012). The Fifth Joint Task Force of the European Society of Cardiology and Other Societies on Cardiovascular Disease Prevention in Clinical Practice (constituted by representatives of nine societies and by invited experts). Developed with the special contribution of the European Association for Cardiovascular Prevention \& Rehabilitation (EACPR). Eur. Heart J. 2012, 33, 1635-1701. [CrossRef] [PubMed]

3. Vaccarino, V.; Bremner, J.D. Behavioral, emotional and neurobiological determinants of coronary heart disease risk in women. Neurosci. Biobehav. Rev. 2017, 74, 297-309. [CrossRef]

4. Vaccarino, V.; Goldberg, J.; Rooks, C.; Shah, A.J.; Veledar, E.; Faber, T.L.; Votaw, J.R.; Forsberg, C.W.; Bremner, J.D. Post-traumatic stress disorder and incidence of coronary heart disease: A twin study. J. Am. Coll. Cardiol. 2013, 62, 97-978. [CrossRef] [PubMed]

5. Vaccarino, V.; Votaw, J.; Faber, T.; Veledar, E.; Murrah, N.V.; Jones, L.R.; Zhao, J.; Su, S.; Goldberg, J.; Raggi, J.P.; et al. Major depression and coronary flow reserve detected by positron emission tomography. Arch. Intern. Med. 2009, 169, 1668-1676. [CrossRef] [PubMed]

6. Carney, R.M.; Freedland, K.E. Depression and coronary heart disease. Nat. Rev. Cardiol. 2017, 14, $145-155$. [CrossRef] [PubMed]

7. Penninx, B.W. Depression and cardiovascular disease: Epidemiological evidence on their linking mechanisms. Neurosci. Biobehav. Rev. 2017, 74, 277-286. [CrossRef] 
8. Freedland, K.E.; Carney, R.M. Depression as a risk factor for adverse outcomes in coronary heart disease. BMC Med. 2013, 11, 131. [CrossRef]

9. Vaccarino, V.; Mayer, E.; Bremner, J.D. Stress and Health. In Posttraumatic Stress Disorder: From Neurobiology to Treatment; Bremner, J.D., Ed.; Wiley-Blackwell Press: Hoboken, NJ, USA, 2016.

10. Vaccarino, V.; Bremner, J.D. Psychiatric and behavioral aspects of cardiovascular disease. In Braunwald's Heart Disease: A Textbook of Cardiovascular Medicine; Zipes, D.P., Libby, P., Bonow, R.O., Mann, D.L., Tomaselli, G.F., Eds.; Elsevier-Saunders: Philadelphia, PA, USA, 2018; pp. 1880-1889.

11. Freeman, M.P.; Rapaport, M.H. Omega-3 fatty acids and depression: From cellular mechanisms to clinical care. J. Clin. Psychiatry 2011, 72, 258-259. [CrossRef]

12. Williamson, D.F.; Thompson, T.J.; Anda, R.F.; Dietz, W.H.; Felitti, V. Body weight and obesity in adulthood and self-reported abuse in childhood. Int. J. Obes. Relat. Metab. Disord. 2002, 26, 1075-1082. [CrossRef]

13. Fowler, N.; Vo, P.T.; Sisk, C.L.; Klump, K.L. Stress as a potential moderator of ovarian hormone influences on binge eating in women. F1000Research 2019, 8. [CrossRef] [PubMed]

14. Moazzami, K.; Lima, B.B.; Sullivan, S.; Shah, A.; Bremner, J.D.; Vaccarino, V. Independent and joint association of obesity and metabolic syndrome with depression and inflammation. Health Psychol. 2019, 38, 586-595. [CrossRef] [PubMed]

15. Bremner, J.D. (Ed.) Posttraumatic Stress Disorder: From Neurobiology to Treatment, 1st ed.; Wiley: Hoboken, NJ, USA, 2016.

16. Valassi, E.; Schacchi, M.; Cavagnini, F. Neuroendocrine control of food intake. Nutr. Metab. Cardiovasc. Dis. 2007, 18, 158-168. [CrossRef] [PubMed]

17. Bremner, J.D. Obesity linked to smaller cerebral volume: What should we make of this? Psychosom. Med. 2009, 71, 483-484. [CrossRef]

18. Mayer, E. The Mind-Gut Connection: How the Hidden Conversation Within Our Bodies Affects Our Mood, Our Choices, and Our Overall Health; HarperCollins: New York, NY, USA, 2016.

19. American Psychiatric Association. The Diagnostic and Statistical Manual of Mental Disorders, Fifth Edition (DSM-5), 5th ed.; American Psychiatric Association: Washington, DC, USA, 2013.

20. Ladabaum, U.; Mannalithara, A.; Myer, P.A.; Singh, G. Obesity, abdominal obesity, physical activity, and caloric intake in US adults: 1988 to 2010. Am. J. Med. 2014, 127, 717-727.e12. [CrossRef]

21. Flegal, K.M.; Carroll, M.D.; Ogden, C.L.; Johnson, C.L. Prevalence and trends in obesity among US adults, 1999-2000. J. Am. Med. Assoc. 2002, 288, 1723-1727. [CrossRef]

22. Hogue, C.W., Jr.; Stearns, J.D.; Colantuoni, E.; Robinson, K.A.; Stierer, T.; Mitter, N.; Pronovost, P.J.; Needham, D.M. The impact of obesity on outcomes after critical illness: A meta-analysis. Intensive Care Med. 2009, 35, 1152-1170. [CrossRef]

23. Bremner, J.D. Before You Take That Pill: Why the Drug Industry May Be Bad for Your Health: Risks and Side Effects You Won't Find on the Label of Commonly Prescribed Drugs, Vitamins, and Supplements; Penguin/Avery: New York, NY, USA, 2008.

24. Pollan, M. The Omnivore's Dilemma: A Natural History of Four Meals; Penguin Press: New York, NY, USA, 2006.

25. Mathes, W.F.; Brownley, K.A.; Mo, X.; Bulik, C.M. The biology of binge eating. Appetite 2009, 52, 545-553. [CrossRef]

26. Olshansky, S.J.; Passaro, D.J.; Hershow, R.C.; Layden, J.; Carnes, B.A.; Brody, J.; Hayflick, L.; Butler, R.N.; Allison, D.B.; Ludwig, D.S. A potential decline in life expectancy in the United States in the 21st century. N. Engl. J. Med. 2005, 352, 1138-1145. [CrossRef]

27. Yusuf, S.; Hawken, S.; Ounpuu, S.; Dans, T.; Avezum, A.; Lanas, F.; McQueen, M.; Budaj, A.; Pais, P.; Varigos, J. Effect of potentially modifiable risk factors associated with myocardial infarction in 52 countries (the INTERHEART study): Case-control study. Lancet 2004, 364, 937-952. [CrossRef]

28. Anand, S.S.; Islam, S.; Rosengren, A.; Franzosi, M.G.; Steyn, K.; Yusufali, A.H.; Keltai, M.; Diaz, R.; Rangarajan, S.; Yusuf, S. Risk factors for myocardial infarction in women and men: Insights from the INTERHEART study. Eur. Heart J. 2008, 29, 932-940. [CrossRef] [PubMed]

29. Zimmet, P.; Alberti, K.G.M.M.; Shaw, J. Global and societal implications of the diabetes epidemic. Nature 2001, 414, 782-787. [CrossRef] [PubMed]

30. World Health Organization. Diabetes. Available online: https://www.who.int/news-room/fact-sheets/detail/ diabetes (accessed on 1 April 2019). 
31. Ko, G.T.; Chan, J.C.; Tsang, L.W.; Yeung, V.T.; Chow, C.C.; Cockram, C.S. Outcomes of screening for diabetes in high-risk Hong Kong Chinese subjects. Diabetes Care 2000, 23, 1290-1294. [CrossRef] [PubMed]

32. Sakurai, Y. Duration of obesity and risk of non-insulin-dependent diabetes mellitus. Biomed. Pharmacother. 2000, 54, 80-84. [CrossRef]

33. Sakurai, Y.; Teruya, K.; Shimada, N.; Umeda, T.; Tanaka, H.; Muto, T.; Kondo, T.; Nakamura, K.; Yoshizawa, N. Association between duration of obesity and risk of non-insulin-dependent diabetes mellitus. The Sotetsu Study. Am. J. Epidemiol. 1999, 149, 256-260. [CrossRef] [PubMed]

34. García-Toro, M.; Vicens-Pons, E.; Gili, M.; Roca, M.; Serrano-Ripoll, M.J.; Vives, M.; Leivad, A.; Yáñez, A.M.; Bennasar-Veny, M.; Oliván-Blázquez, B. Obesity, metabolic syndrome and Mediterranean diet: Impact on depression outcome. J. Affect. Disord. 2016, 194, 105-108. [CrossRef]

35. Tuomilehto, J.; Lindstrom, J.; Eriksson, J.G.; Valle, T.T.; Halalainen, H.; Ilanne-Parikka, P.; Keinanen-Kiukaanniemi, S.; Laakso, M.; Louheranta, A.; Rastas, M.; et al. Prevention of type 2 diabetes mellitus by changes in lifestyle among subjects with impaired glucose tolerance. N. Engl. J. Med. 2001, 344, 1343-1350. [CrossRef]

36. Halton, T.L.; Willett, W.C.; Liu, S.; Manson, J.E.; Albert, C.M.; Rexrode, K.; Hu, F.B. Low-carbohydrate-diet score and the risk of coronary heart disease in women. N. Engl. J. Med. 2006, 355, 1991-2002. [CrossRef]

37. de Lorgeril, M.; Salen, P.; Martin, J.L.; Monjaud, I.; Delaye, J.; Mamelle, N. Mediterranean diet, traditional risk factors, and the rate of cardiovascular complications after myocardial infarction: Final report of the Lyon Diet Heart Study. Circulation 1999, 99, 779-785. [CrossRef]

38. Dai, J.; Lampert, R.; Wilson, P.W.; Goldberg, J.; Ziegler, T.R.; Vaccarino, V. Mediterranean dietary pattern is associated with improved cardiac autonomic function among middle-aged men: A twin study. Circ. Cardiovasc. Qual. Outcomes 2010, 3, 366-373. [CrossRef]

39. Trichopoulou, A.; Orfanos, P.; Norat, T.; Bueno-de-Mesquita, B.; Ocke, M.C.; Peeters, P.H.M.; van der Schouw, Y.T.; Boeing, H.; Hoffmann, K.; Boffetta, P.; et al. Modified Mediterranean diet and survival: EPIC-elderly prospective cohort study. Br. Med. J. 2005, 330, 991-998. [CrossRef] [PubMed]

40. Fung, T.T.; Rexrode, K.M.; Mantzoros, C.S.; Manson, J.E.; Willett, W.C.; Hu, F.B. Mediterranean diet and incidence of and mortality from coronary heart disease and stroke in women. Circulation 2009, 119, 1093-1100. [CrossRef] [PubMed]

41. Estruch, R.; Ros, E.; Salas-Salvadó, J.; Covas, M.-I.; Corella, D.; Arós, F.; Gómez-Gracia, E.; Ruiz-Gutiérrez, V.; Fiol, M.; Lapetra, J.; et al. Primary prevention of cardiovascular disease with a Mediterranean Diet supplemented with extra-virgin olive oil or nuts. N. Engl. J. Med. 2018, 378, e34. [CrossRef] [PubMed]

42. Markowitz, S.; Friedman, M.A.; Arent, S.M. Understanding the relation between obesity and depression: Causal mechanisms and implications for treatment. Clin. Psychol. Sci. Pr. 2008, 15, 1-20. [CrossRef]

43. Fernanda Fernandes, M.; Mutch, D.M.; Leri, F. The relationship between fatty acids and different depression-related brain regions, and their potential role as biomarkers of response to antidepressants. Nutrients 2017, 9, 298. [CrossRef]

44. Weltens, N.; Zhao, D.; Van Oudenhove, L. Where is the comfort in comfort foods? Mechanisms linking fat signaling, reward, and emotion. Neurogastroenterol. Motil. 2014, 26, 303-315. [CrossRef]

45. Van Oudenhove, L.; McKie, S.; Lassman, D.; Uddin, B.; Paine, P.; Coen, S.; Gregory, L.; Tack, J.; Aziz, Q. Fatty acid-induced gut-brain signaling attenuates neural and behavioral effects of sad emotion in humans. J. Clin. InvestIG. 2011, 121, 3094-3099. [CrossRef]

46. Tomiyama, A.J.; Dallman, M.F.; Epel, E.S. Comfort food is comforting to those most stressed: Evidence of the chronic stress response network in high stress women. Psychoneuroendocrinology 2011, 36, 1513-1519. [CrossRef]

47. Shively, C.A.; Register, T.C.; Clarkson, T.B. Social stress, visceral obesity, and coronary artery atherosclerosis: Product of a primate adaptation. Am. J. Primatol. 2009, 71, 742-751. [CrossRef]

48. Dong, M.; Giles, W.H.; Felitti, V.J.; Dube, S.R.; Williams, J.E.; Chapman, D.P.; Anda, R.F. Insights into causal pathways for ischemic heart disease: Adverse childhood experiences study. Circulation 2004, 110, 1761-1766. [CrossRef]

49. Rich-Edwards, J.W.; Spiegelman, D.; Lividoti Hibert, E.N.; Jun, H.J.; Todd, T.J.; Kawachi, I.; Wright, R.J. Abuse in childhood and adolescence as a predictor of type 2 diabetes in adult women. Am. J. Prev. Med. 2010, 39, 529-536. [CrossRef] [PubMed] 
50. Su, S.; Jimenez, M.P.; Roberts, C.T.; Loucks, E.B. The role of adverse childhood experiences in cardiovascular disease risk: A review with emphasis on plausible mechanisms. Curr. Cardiol. Rep. 2015, 17, 88. [CrossRef] [PubMed]

51. Hamilton, M.K.; Boudry, G.; Lemay, D.G.; Raybould, H.E. Changes in intestinal barrier function and gut microbiota in high fat diet-fed rats are dynamic and region dependent. Am. J. Physiol. Gastrointest. Liver Physiol. 2015, 308, G840-G851. [CrossRef] [PubMed]

52. Mayer, E.A.; Tillisch, K.; Gupta, A. Gut/brain axis and the microbiota. J. Clin. Investig. 2015, 125, 926-938. [CrossRef] [PubMed]

53. Anda, R.F.; Felitti, V.J.; Walker, J.; Whitfield, C.; Bremner, J.D.; Perry, B.D.; Dube, S.R.; Giles, W.H. The enduring effects of childhood abuse and related experiences in childhood: A convergence of evidence from neurobiology and epidemiology. Eur. Arch. Psychiatry Clin. Neurosci. 2006, 256, 174-186. [CrossRef]

54. Lin, P.-Y.; Su, K.-P. A meta-analytic review of double-blind, placebo-controlled trials of antidepressant efficacy of omega-3 fatty acids. J. Clin. Psychiatry 2007, 68, 1056-1061. [CrossRef]

55. Lacasse, J.R.; Leo, J. Serotonin and depression: A disconnect between the advertisements and the scientific literature. PLoS Med. 2005, 2, e392. [CrossRef]

56. Wells, A.S.; Read, N.W.; Uvnas-Moberg, K.; Alster, P. Influences of fat and carbohydrate on postprandial sleepiness, mood, and hormones. Physiol. Behav. 1997, 61, 679-686. [CrossRef]

57. Wells, A.S.; Read, N.W.; Macdonald, I.A. Effects of carbohydrate and lipid on resting energy expenditure, heart rate, sleepiness, and mood. Physiol. Behav. 1998, 63, 621-628. [CrossRef]

58. Pischke, C.R.; Frenda, S.; Ornish, D.; Weidner, G. Lifestyle changes are related to reductions in depression in persons with elevated coronary risk factors. Psychol. Health 2010, 29, 1-24. [CrossRef]

59. Pellegrin, K.L.; O’Neil, P.M.; Stellefson, E.J.; Fossey, M.D.; Ballenger, J.C.; cochrane, C.E.; Currey, H.S. Average daily nutrient intake and mood among obese women. Nutr. Res. 1998, 18, 1103-1112. [CrossRef]

60. Sánchez-Villegas, A.; Delgado-Rodríguez, M.; Alonso, A.; Schlatter, J.; Lahortiga, F.; Serra Majem, L.; Martínez-González, M.A. Association of the Mediterranean dietary pattern with the incidence of depression: The Seguimiento Universidad de Navarra/University of Navarra follow-up (SUN) cohort. Arch. Gen. Psychiatry 2009, 66, 1090-1098. [CrossRef] [PubMed]

61. Firth, J.; Marx, W.; Dash, S.; Carney, R.; Teasdale, S.B.; Solmi, M.; Stubbs, B.; Schuch, F.B.; Carvalho, A.F.; Jacka, F; et al. The effects of dietary improvement on symptoms of depression and anxiety: A meta-analysis of randomized controlled trials. Psychosom. Med. 2019, 81, 265-280. [CrossRef] [PubMed]

62. Agarwal, U.; Mishra, S.; Xu, J.; Levin, S.; Gonzales, J.; Barnard, N.D. A multicenter randomized controlled trial of a nutrition intervention program in a multiethnic adult population in the corporate setting reduces depression and anxiety and improves quality of life: The GEICO study. Am. J. Health Promot. 2015, 29, 245-254. [CrossRef] [PubMed]

63. ndevelt, R.; Lemberger, J.; Bregman, J.; Kowen, G.; Berger-Fecht, I.; Lander, H.; Karpati, T.; Shahar, D. Intensive dietary intervention by a dietitian as a case manager among community dwelling older adults: The EDIT study. J. Nutr. Health Aging 2011, 15, 624-630. [CrossRef]

64. Forster, S.E.; Powers, H.J.; Foulds, G.A.; Flower, D.J.; Hopkinson, K.; Parker, S.G.; Young, T.A.; Saxton, J.; Pockley, A.G.; Williams, E.A. Improvement in nutritional status reduces the clinical impact of infections in older adults. J. Am. Geriatr. Soc. 2012, 60, 1645-1654. [CrossRef]

65. Scheier, M.F.; Helgeson, V.S.; Schulz, R.; Colvin, S.; Berga, S.; Bridges, M.W.; Knapp, J.; Gerszten, K.; Pappert, W.S. Interventions to enhance physical and psychological functioning among younger women who are ending nonhormonal adjuvant treatment for early-stage breast cancer. J. Clin. Oncol. 2005, 23, 4298. [CrossRef]

66. Halyburton, A.K.; Brinkworth, G.D.; Wilson, C.J.; Noakes, M.; Buckley, J.D.; Keogh, J.B.; Clifton, P.M. Lowand high-carbohydrate weight-loss diets have similar effects on mood but not cognitive performance. Am. J. Clin. Nutr. 2007, 86, 580-587. [CrossRef]

67. Assaf, A.R.; Beresford, S.A.; Risica, P.M.; Aragaki, A.; Brunner, R.L.; Bowen, D.J.; Naughton, M.; Rosal, M.C.; Snetselaar, L.; Wenger, N. Low-fat dietary pattern intervention and health-related quality of life: The Women's Health Initiative randomized controlled dietary modification trial. J. Acad. Nutr. Diet. 2016, 116, 259-271. [CrossRef]

68. Nieman, D.C.; Custer, W.F.; Butterworth, D.E.; Utter, A.C.; Henson, D.A. Psychological response to exercise training and/or energy restriction in obese women. J. Psychosom. Res. 2000, 48, 23-29. [CrossRef] 
69. Kiernan, M.; King, A.C.; Stefanick, M.L.; Killen, J.D. Men gain additional psychological benefits by adding exercise to a weight-loss program. Obesity 2001, 9, 770-777. [CrossRef] [PubMed]

70. Jenkinson, C.M.; Doherty, M.; Avery, A.J.; Read, A.; Taylor, M.A.; Sach, T.H.; Silcocks, P.; Muir, K.R. Effects of dietary intervention and quadriceps strengthening exercises on pain and function in overweight people with knee pain: Randomised controlled trial. Br. Med. J. 2009, 339, b3170. [CrossRef] [PubMed]

71. Serrano Ripoll, M.J.; Oliván-Blázquez, B.; Vicens-Pons, E.; Roca, M.; Gili, M.; Leiva, A.; García-Campayo, J.; Demarzo, M.P.; García-Toro, M. Lifestyle change recommendations in major depression: Do they work? J. Affect. Disord. 2015, 183, 221-228. [CrossRef] [PubMed]

72. Wardle, J.; Rogers, P.; Judd, P.; Taylor, M.A.; Rapoport, L.; Green, M.; Nicholson Perry, K. Randomized trial of the effects of cholesterol-lowering dietary treatment on psychological function. Am. J. Med. 2000, 108, 547-553. [CrossRef]

73. Hyyppä, M.T.; Kronholm, E.; Virtanen, A.; Leino, A.; Jula, A. Does simvastatin affect mood and steroid hormone levels in hypercholesterolemic men? A randomized double-blind trial. Psychoneuroendocrinology 2003, 28, 181-194. [CrossRef]

74. McMillan, L.; Owen, L.; Kras, M.; Scholey, A. Behavioural effects of a 10-day Mediterranean diet. Results from a pilot study evaluating mood and cognitive performance. Appetite 2011, 56, 143-147. [CrossRef]

75. Garcia-Toro, M.; Ibarra, O.; Gili, M.; Salva, J.; Monzón, S.; Vives, M.; Serrano, M.J.; Garcia-Campayo, J.; Roca, M. Effectiveness of hygienic-dietary recommendations as enhancers of antidepressant treatment in patients with Depression: Study protocol of a randomized controlled trial. BMC Public Health 2010, 10, 404. [CrossRef]

76. Toobert, D.J.; Glasgow, R.E.; Strycker, L.A.; Barrera, M.; Ritzwoller, D.P.; Weidner, G. Long-term effects of the Mediterranean lifestyle program: A randomized clinical trial for postmenopausal women with type 2 diabetes. Int. J. Behav. Nutr. Phys. Act. 2007, 4, 1-7. [CrossRef]

77. Garcia-Toro, M.; Gili, M.; Ibarra, O.; Monzón, S.; Vives, M.; Garcia-Campayo, J.; Gomez-Juanes, R.; Roca, M. Metabolic syndrome improvement in depression six months after prescribing simple hygienic-dietary recommendations. BMC Res. Notes 2014, 7, 339. [CrossRef]

78. Kasckow, J.; Klaus, J.; Morse, J.; Oslin, D.; Luther, J.; Fox, L.; Reynolds, C.; Haas, G.L. Using problem solving therapy to treat veterans with subsyndromal depression: A pilot study. Int. J. Geriatr. Psychiatry 2014, 29, 1255-1261. [CrossRef]

79. Kasckow, J.; Morse, J.; Begley, A.; Anderson, S.; Bensasi, S.; Thomas, S.; Quinn, S.C.; Reynolds, C.F.r. Treatment of post-traumatic stress disorder symptoms in emotionally distressed individuals. Psychiatry Res. 2014, 220, 370-375. [CrossRef] [PubMed]

80. Jacka, F.N.; O’Neil, A.; Opie, R.; Itsiopoulos, C.; Cotton, S.; Mohebbi, M.; Castle, D.; Dash, S.; Mihalopoulos, C.; Chatterton, M.L.; et al. A randomised controlled trial of dietary improvement for adults with major depression (the 'SMILES' trial). BMC Med. 2017, 15, 23. [CrossRef] [PubMed]

81. Castro-Diehl, C.; Wood, A.C.; Redline, S.; Reid, M.; Johnson, D.A.; Maras, J.E.; Jacobs, D.R., Jr.; Shea, S.; Crawford, A.; St-Onge, M.P. Mediterranean diet pattern and sleep duration and insomnia symptoms in the Multi-Ethnic Study of Atherosclerosis. Sleep 2018, 41. [CrossRef] [PubMed]

82. Campanini, M.Z.; Guallar-Castillon, P.; Rodriguez-Artalejo, F.; Lopez-Garcia, E. Mediterranean Diet and Changes in Sleep Duration and Indicators of Sleep Quality in Older Adults. Sleep 2017, 40. [CrossRef] [PubMed]

83. Mamalaki, E.; Anastasiou, C.A.; Ntanasi, E.; Tsapanou, A.; Kosmidis, M.H.; Dardiotis, E.; Hadjigeorgiou, G.M.; Sakka, P.; Scarmeas, N.; Yannakoulia, M. Associations between the mediterranean diet and sleep in older adults: Results from the hellenic longitudinal investigation of aging and diet study. Geriatr. Gerontol. Int. 2018, 18, 1543-1548. [CrossRef]

84. Jaussent, I.; Dauvilliers, Y.; Ancelin, M.L.; Dartigues, J.F.; Tavernier, B.; Touchon, J.; Ritchie, K.; Besset, A. Insomnia symptoms in older adults: Associated factors and gender differences. Am. J. Geriatr. Psychiatry 2011, 19, 88-97. [CrossRef]

85. Liu, Q.; Wu, D.; Ni, N.; Ren, H.; Luo, C.; He, C.; Kang, J.-X.; Wan, J.-B.; Su, H. Omega-3 polyunsaturated fatty acids protect neural progenitor cells against oxidative injury. Mar. Drugs 2014, 12, 2341-2356. [CrossRef]

86. Russell, F.D.; Bürgin-Maunder, C.S. Distinguishing health benefits of eicosapentaenoic and docosahexaenoic acids. Mar. Drugs 2012, 10, 2535-2559. [CrossRef] 
87. Brouwer, I.A.; Zock, P.L.; Camm, A.J.; Bocker, D.; Hauer, R.N.W.; Wever, E.F.D.; Dullemeijer, C.; Ronden, J.E.; Katan, M.B.; Lubinski, A.; et al. Effect of fish oil on ventricular tachyarrhythmia and death in patients with implantable cardioverter defibrillators: The study on Omega-3 fatty acids and ventricular arrhthmia (SOFA) randomized trial. J. Am. Med. Assoc. 2006, 295, 2613-2619. [CrossRef]

88. Burr, M.L.; Fehily, A.M.; Gilbert, J.F.; Rogers, S.; Holliday, R.M.; Sweetnam, P.M. Effects of changes in fat, fish, and fibre intakes on death and myocardial reinfarction. Lancet 1989, 2, 757-761. [CrossRef]

89. Hooper, L.; Thompson, R.L.; Harrison, R.A.; Summerbell, C.D.; Ness, A.R.; Moore, H.J.; Worthington, H.V.; Durrington, P.N.; Higgins, J.P.; Capps, N.E.; et al. Risks and benefits of omega 3 fats for mortality, cardiovascular disease, and cancer: Systematic review. BMJ 2006, 332, 752-760. [CrossRef] [PubMed]

90. Bremner, J.D.; McCaffery, P. The neurobiology of retinoic acid in affective disorders. Prog. Neuropsychopharmacol. Biol. Psychiatry 2008, 32, 315-331. [CrossRef] [PubMed]

91. Danese, A.; Moffitt, T.E.; Pariante, C.M.; Ambler, A.; Poulton, R.; Caspi, A. Elevated inflammation levels in depressed adults with a history of childhood maltreatment. Arch. Gen. Psychiatry 2008, 65, 409-415. [CrossRef] [PubMed]

92. Miller, A.H.; Raison, C.L. The role of inflammation in depression: From evolutionary imperative to modern treatment target. Nat. Rev. Immunol. 2016, 16, 22-34. [CrossRef]

93. Miller, A.H.; Maletic, V.; Raison, C.L. Inflammation and its discontents: The role of cytokines in the pathphysiology of depression. Biol. Psychiatry 2009, 65, 732-741. [CrossRef] [PubMed]

94. Rapaport, M.H.; Nierenberg, A.A.; Schettler, P.J.; Kinkead, B.; Cardoos, A.; Walker, R.; Mischoulon, D. Inflammation as a predictive biomarker for response to omega-3 fatty acids in major depressive disorder: A proof-of-concept study. Mol. Psychiatry 2016, 21, 71-79. [CrossRef]

95. Allam-Ndoul, B.; Guénard, F.; Barbier, O.; Vohl, M.-C. Effect of n-3 fatty acids on the expression of inflammatory genes in THP-1 macrophages. Lipids Health Dis. 2016, 15, 1-7. [CrossRef]

96. Guo, H.; Callaway, J.B.; Ting, J.P.-Y. Inflammasomes: Mechanism of action, role in disease, and therapeutics. Nat. Med. 2015, 21, 677-687. [CrossRef]

97. Lima, B.B.; Hammadah, M.; Wilmot, K.; Pearce, B.D.; Shah, A.; Levantsevych, O.; Kaseer, B.; Obideen, M.; Gafeer, M.M.; Kim, J.H.; et al. Posttraumatic Stress Disorder is associated with enhanced interleukin-6 response to mental stress in subjects with a recent myocardial infarction. Brain. Behav. Immun. 2019, 75, 26-33. [CrossRef]

98. Serhan, C.N. Novel pro-resolving lipid mediators in inflammation are leads for resolution physiology. Nature 2014, 510, 92-101. [CrossRef]

99. Chiang, N.; Serhan, C.N. Structural elucidation and physiologic functions of specialized pro-resolving mediators and their receptors. Mol. Asp. Med. 2017, 58, 114-129. [CrossRef] [PubMed]

100. Oh, S.F.; Dona, M.; Fredman, G.; Krishnamoorthy, S.; Irimia, D.; Serhan, C.N. Resolvin E2 formation and impact in inflammation-resolution. J. Immunol. 2012, 188, 4527-4534. [CrossRef] [PubMed]

101. Deyama, S.; Ishikawa, Y.; Yoshikawa, K.; Shimoda, K.; Ide, S.; Satoh, M.; Minami, M. Resolvin D1 and D2 reverse lipopolysaccharide-induced depression-like behaviors through the mTORC1 signaling pathway. Int. J. Neuropsychopharmacol. 2017, 20, 575-584. [CrossRef] [PubMed]

102. Gilbert, K.; Bernier, J.; Godbout, R.; Rousseau, G. Resolvin D1, a metabolite of omega-3 polyunsaturated fatty acid, decreases post-myocardial infarct depression. Mar. Drugs 2014, 12, 5306-5407. [CrossRef] [PubMed]

103. Deyama, S.; Shimoda, K.; Suzuki, H.; Ishikawa, Y.; Ishimura, K.; Fukuda, H.; Hitora-Imamura, N.; Ide, S.; Satoh, M.; Kaneda, K.; et al. Resolvin E1/E2 ameliorate lipopolysaccharide-induced depression-like behaviors via ChemR23. Psychopharmacology 2018, 235, 329-336. [CrossRef]

104. Ishikawaa, Y.; Deyamaa, S.; Shimodaa, K.; Yoshikawaa, K.; Idea, S.; Satohd, M.; Minamia, M. Rapid and sustained antidepressant effects of resolvin D1 and D2 in a chronic unpredictable stress model. Behav. Brain Res. 2017, 332, 233-236. [CrossRef]

105. Alcocer-Gómez, E.; de Miguel, M.; Casas-Barquero, N.; Núñez-Vasco, J.; Sánchez-Alcazar, J.A.; Fernández-Rodríguez, A.; Cordero, M.D. NLRP3 inflammasome is activated in mononuclear blood cells from patients with major depressive disorder. Brain. Behav. Immun. 2014, 36, 111-117. [CrossRef]

106. Akosile, W.; Voisey, J.; Lawford, B.; Colquhounc, D.; Young, R.M.; Mehta, D. The inflammasome NLRP12 is associated with both depression and coronary artery disease in Vietnam veterans. Psychiatry Res. 2018, 270, 775-779. [CrossRef] 
107. Vaccarino, V.; Brennan, M.L.; Miller, A.H.; Bremner, J.D.; Ritchie, J.C.; Lindau, F.; Veledar, E.; Su, S.; Murrah, N.V.; Jones, L.; et al. Association of major depressive disorder with serum myeloperoxidase and other markers of inflammation: A twin study. Biol. Psychiatry 2008, 64, 476-483. [CrossRef]

108. Kiecolt-Glaser, J.K.; Belury, M.A.; Porter, K.; Beversdorf, D.Q.; Lemeshow, S.; Glaser, R. Depressive symptoms, omega-6 fatty acids, and inflammation in older adults. Psychosom. Med. 2007, 69, 217-224. [CrossRef]

109. Sublette, M.E.; Hibbeln, J.R.; Galfalvy, H.; Oquendo, M.A.; Mann, J.J. Omega-3 polyunsaturated essential fatty acid status as a predictor of future suicide risk. Am. J. Psychiatry 2006, 163, 1100-1102. [CrossRef] [PubMed]

110. Capuron, L.; Su, S.; Miller, A.H.; Bremner, J.D.; Goldberg, J.; Vogt, G.J.; Maisano, C.; Jones, L.; Murrah, N.V.; Vaccarino, V. Depressive symptoms and metabolic syndrome: Is inflammation the underlying link? Biol. Psychiatry 2008, 64, 896-900. [CrossRef] [PubMed]

111. Gharekhani, A.; Khatami, M.-R.; Dashti-Khavidaki, S.; Razeghi, E.; Noorbala, A.-A.; Hashemi-Nazari, S.-S.; Mansournia, M.-A. The effect of omega-3 fatty acids on depressive symptoms and inflammatory markers in maintenance hemodialysis patients: A randomized, placebo-controlled clinical trial. Eur. J. Clin. Pharmacol. 2014, 70, 655-665. [CrossRef]

112. Su, K.-P.; Lai, H.-C.; Yang, H.-T.; Su, W.-P.; Peng, C.-Y.; Chang, J.P.-C.; Chang, H.-C.; Pariante, C.M. Omega-3 fatty acids in the prevention of interferon-alpha-induced depression: Results from a randomized, controlled trial. Biol. Psychiatry 2014, 76, 559-566. [CrossRef] [PubMed]

113. Poppitt, S.D.; Howe, C.A.; Lithander, F.E.; Silvers, K.M.; Lin, R.B.; Croft, J.; Ratnasabapathy, Y.; Gibson, R.A.; Anderson, C.S. Effects of moderate-dose omega-3 fish oil on cardiovascular risk factors and mood after ischemic stroke: A randomized, controlled trial. Stroke 2009, 40, 3485-3492. [CrossRef]

114. Sinn, N.; Milte, C.M.; Street, S.J.; Buckley, J.D.; Coates, A.M.; Petkov, J.; Howe, P.R. Effects of n-3 fatty acids, EPA v. DHA, on depressive symptoms, quality of life, memory and executive function in older adults with mild cognitive impairment: A 6-month randomised controlled trial. Br. J. Nutr. 2012, 107, 1682-1693. [CrossRef]

115. Einvik, G.; Ekeberg, O.; Lavik, J.G.; Ellingsen, I.; Klemsdal, T.O.; Hjerkinn, E. The influence of long-term awareness of hyperlipidemia and of 3 years of dietary counseling on depression, anxiety, and quality of life. J. Psychosom. Res. 2010, 68, 567-572. [CrossRef]

116. Andreeva, V.A.; Galan, P.; Torres, M.; Julia, C.; Hercberg, S.; Kesse-Guyot, E. Supplementation with B vitamins or $\mathrm{n}-3$ fatty acids and depressive symptoms in cardiovascular disease survivors: Ancillary findings from the SUpplementation with FOLate, vitamins B-6 and B-12 and/or OMega-3 fatty acids (SU.FOL.OM3) randomised trial. Am. J. Clin. Nutr. 2012, 96, 208-214. [CrossRef]

117. Giltay, E.J.; Geleijnse, J.M.; Kromhout, D. Effects of n-3 fatty acids on depressive symptoms and dispositional optimism after myocardial infarction. Am. J. Clin. Nutr. 2011, 94, 1442-1450. [CrossRef]

118. Doornbos, B.; van Goor, S.A.; Dijck-Brouwer, D.A.; Schaafsma, A.; Korf, J.; Muskiet, F.A. Supplementation of a low dose of DHA or DHA+AA does not prevent peripartum depressive symptoms in a small population based sample. Prog. Neuro-Psychopharmacol. Biol. Psychiatry 2009, 33, 49-52. [CrossRef]

119. Llorente, A.M.; Jensen, C.L.; Voigt, R.G.; Fraley, J.K.; Berretta, M.C.; Heird, W.C. Effect of maternal docosahexaenoic acid supplementation on postpartum depression and information processing. Am. J. Obstet. Gynecol. 2003, 188, 1348-1353. [CrossRef] [PubMed]

120. Makrides, M.; Gibson, R.A.; McPhee, A.J.; Yelland, L.; Quinlivan, J.; Ryan, P.; the DOMInO Investigative Team. Effect of DHA supplementation during pregnancy on maternal depression and neurodevelopment of young children: A randomized controlled trial. JAMA 2010, 304, 1675-1683. [CrossRef] [PubMed]

121. Mozurkewich, E.L.; Clinton, C.M.; Chilimigras, J.L.; Hamilton, S.E.; Allbaugh, L.J.; Berman, D.R.; Marcus, S.M.; Romero, V.C.; Treadwell, M.C.; Keeton, K.L.; et al. The Mothers, Omega-3, and Mental Health Study: A double-blind, randomized controlled trial. Am. J. Obstet. Gynecol. 2013, 208, e1-9. [CrossRef]

122. Stoll, A.L.; Severus, E.; Freeman, M.P.; Rueter, S.; Zboyan, H.A.; Diamond, E.; Cress, K.K.; Marangell, L.B. Omega 3 fatty acids in bipolar disorder: A preliminary double-blind, placebo-controlled trial. Arch. Gen. Psychiatry 1999, 56, 407-412. [CrossRef] [PubMed]

123. Freeman, M.P.; Hibbeln, J.R.; Wisner, K.L.; Davis, J.M.; Mischoulon, D.; Peet, M.; Keck, P.E.; Marangell, L.B.; Richardson, A.J.; Lake, J.; et al. Omega-3 fatty acids: Evidence basis of treatment and future research in psychiatry. J. Clin. Psychiatry 2006, 67, 1954-1967. [CrossRef] 
124. Peet, M.; Horrobin, D.F. A dose-ranging study of the effects of ethyl-eicosapentaenoate in patients with ongoing depression despite apparently adequate treatment with standard drugs. Arch. Gen. Psychiatry 2002, 59, 913-919. [CrossRef]

125. Su, K.P.; Huang, S.Y.; Chiu, T.-H.; Huang, K.-C.; Huang, C.-L.; Chang, H.-C.; Pariante, C.M. Omega-3 fatty acids for major depressive disorder during pregnancy: Results from a randomized, double-blind, placebo-controlled trial. J. Clin. Psychiatry 2008, 69, 644-651. [CrossRef]

126. Nemets, H.; Nemets, B.; Apter, A.; Bracha, Z.; Belmaker, R.H. Omega-3 treatment of childhood depression: A controlled, double-blind pilot study. Am. J. Psychiatry 2006, 163, 1098-1100. [CrossRef]

127. Freeman, M.P.; Davis, M.; Sinha, P.; Wisner, K.L.; Hibbeln, J.R.; Gelenberg, A.J. Omega-3 fatty acids and supportive psychotherapy for perinatal depression: A randomized placebo-controlled study. J. Affect. Disord. 2008, 110, 142-148. [CrossRef]

128. Parker, G.; Gibson, N.A.; Brotchie, H.; Heruc, G.; Rees, A.M.; Hadzi-Pavlovic, D. Omega-3 fatty acids and mood disorders. Am. J. Psychiatry 2006, 163, 969-978. [CrossRef]

129. Grosso, G.; Pajak, A.; Marventano, S.; Castellano, S.; Galvano, F.; Bucolo, C.; Drago, F.; Caraci, F. Role of omega-3 fatty acids in the treatment of depressive disorders: A comprehensive meta-analysis of randomized clinical trials. PLoS ONE 2014, 9, e96905. [CrossRef] [PubMed]

130. Hallahan, B.; Ryan, T.; Hibbeln, J.R.; Murray, I.T.; Glynn, S.; Ramsden, C.E.; SanGiovanni, J.P.; Davis, J.M. Efficacy of omega-3 highly unsaturated fatty acids in the treatment of depression. Br. J. Psychiatry 2016, 209, 192-201. [CrossRef] [PubMed]

131. Martins, J.G.; Bentsen, H.; Puri, B.K. Eicosapentaenoic acid appears to be the key omega-3 fatty acid component associated with efficacy in major depressive disorder: A critique of Bloch and Hannestad and updated metaanalysis. Mol. Psychiatry 2012, 17, 1144-1149. [CrossRef] [PubMed]

132. Mocking, R.J.; Harmsen, I.; Assies, J.; Koeter, M.W.; Ruhé, H.G.; Schene, A.H. Metaanalysis and meta-regression of omega-3 polyunsaturated fatty acid supplementation for major depressive disorder. Transl. Psychiatry 2016, 6, e756. [CrossRef] [PubMed]

133. Sublette, M.E.; Ellis, S.P.; Geant, A.L.; Mann, J.J. Metaanalysis of the effects of eicosapentaenoic acid (EPA) in clinical trials in depression. J. Clin. Psychiatry 2011, 72, 1577-1584. [CrossRef]

134. Appleton, K.M.; Rogers, P.J.; Ness, A.R. Updated systematic review and meta-analysis of the effects of n-3 long-chain polyunsaturated fatty acids on depressed mood. Am. J. Clin. Nutr. 2010, 91,757-770. [CrossRef]

135. Gertsik, L.; Poland, R.E.; Bresee, C.; Rapaport, M.H. Omega-3 fatty acid augmentation of citalopram treatment for patients with major depressive disorder. J. Clin. Psychopharmacol. 2012, 32, 61-64. [CrossRef]

136. Lesperance, F.; Frasure-Smith, N.; St-Andre, E.; Turecki, G.; Lesperance, P.; Wisniewski, S.R. The efficacy of omega-3 supplementation for major depression: A randomized controlled trial. J. Clin. Psychiatry 2011, 72, 1054-1062. [CrossRef]

137. Felger, J.C.; Li, Z.; Haroon, E.; Woolwine, B.J.; Jung, M.Y.; Hu, X.; Miller, A.H. Inflammation is associated with decreased functional connectivity within corticostriatal reward circuitry in depression. Mol. Psychiatry 2016, 21, 1358-1365. [CrossRef]

138. Bot, M.; Pouwer, F.; Assies, J.; Jansen, E.H.; Diamant, M.; Snoek, F.J.; Beekman, A.T.; de Jonge, P. Eicosapentaenoic acid as an add-on to antidepressant medication for co-morbid major depression in patients with diabetes mellitus: A randomized, double-blind placebo controlled study. J. Affect. Disord. 2010, 126, 282-286. [CrossRef]

139. da Silva, T.M.; Munhoz, R.P.; Alvarez, C.; Naliwaiko, K.; Kiss, A.; Andreatini, R.; Ferraz, A.C. Depression in Parkinson's disease: A double-blind, randomized, placebo-controlled pilot study of omega-3 fatty-acid supplementation. J. Affect. Disord. 2008, 111, 351-359. [CrossRef] [PubMed]

140. Grenyer, B.F.S.; Crowe, T.; Meyer, B.; Owen, A.J.; Grigonis-Deane, E.M.; Caputi, P.; Howe, P.R.C. Fish oil supplementation in the treatment of major depression: A randomised double-blind placebo-controlled trial. Prog. Neuropsychopharmacol. Biol. Psychiatry 2007, 31, 1393-1396. [CrossRef] [PubMed]

141. Silvers, K.M.; Woolley, C.C.; Hamilton, F.C.; Watts, P.M.; Watson, R.A. Randomised double-blind placebo-controlled trial of fish oil in the treatment of depression. Prostaglandins Leukot. Essent. Fat. Acids 2005, 72, 211-218. [CrossRef] [PubMed] 
142. Tayama, J.; Ogawa, S.; Nakaya, N.; Sone, T.; Hamaguchi, T.; Takeoka, A.; Hamazaki, K.; Okamura, H.; Yajima, J.; Kobayashi, M.; et al. Omega-3 polyunsaturated fatty acids and psychological intervention for workers with mild to moderate depression: A double-blind randomized controlled trial. J. Affect. Disord. 2019, 245, 364-370. [CrossRef]

143. Marangell, L.B.; Martinez, J.M.; Zboyan, H.A.; Kertz, B.; Seung Kim, H.F.; Puryear, L.J. A double-blind, placebo-controlled study of the omega-3 fatty acid docosahexaenoic acid in the treatment of major depression. Am. J. Psychiatry 2003, 160, 996-998. [CrossRef]

144. Mischoulon, D.; Papakostas, G.I.; Dording, C.M.; Farabaugh, A.H.; Sonawalla, S.B.; Agoston, A.M.; Smith, J.; Beaumont, E.C.; Dahan, L.E.; Alpert, J.E.; et al. A double-blind, randomized controlled trial of ethyl-eicosapentaenoate for major depressive disorder. J. Clin. Psychiatry 2009, 70, 1636-1644. [CrossRef]

145. Rees, A.-M.; Austin, M.-P.; Parker, G.B. Omega-3 fatty acids as a treatment for perinatal depression: Randomized double-blind placebo-controlled trial. Aust. N. Z. J. Psychiatry 2008, 42, 199-205. [CrossRef]

146. Carney, R.M.; Freedland, K.E.; Rubin, E.H.; Rich, M.W.; Steinmeyer, B.C.; Harris, W.S. Omega-3 augmentation of sertraline in treatment of depression in patients with coronary heart disease: A randomized controlled trial. J. Am. Med. Assoc. 2009, 302, 1651-1657. [CrossRef]

147. Carney, R.M.; Freedland, K.E.; Rubin, E.H.; Rich, M.W.; Steinmeyer, B.C.; Harris, W.S. A randomized placebo-controlled trial of omega-3 and sertraline in depressed patients with or at risk for coronary heart disease. J. Clin. Psychiatry 2019, 80, 19m12742. [CrossRef]

148. Almeida, O.P.; Flicker, L.; Lautenshlager, N.T.; Leedman, P.; Vasikaran, S.; van Bockxmeer, F.M. Contribution of the MTHFR gene to the causal pathway for depression, anxiety and cognitive impairment in later life. Neurobiol. Aging 2005, 26, 251-257. [CrossRef]

149. Bressa, G.M. S-adenosyl-1-methionine (SAMe) as antidepressant: Meta-analysis of clinical studies. Acta Neurol. Scand. 1994, 89, 7-14. [CrossRef] [PubMed]

150. Bottiglieri, T. Homocysteine and folate metabolism in depression. Prog. Neuropsychopharmacol. Biol. Psychiatry 2005, 29, 1103-1112. [CrossRef] [PubMed]

151. Tolmunen, T.; Hintikka, J.; Voutilainene, S.; Ruusunen, A.; Alfthan, G.; Nyyssonen, K.; Viinamaki, H.; Kaplan, G.A.; Salonen, J.T. Association between depressive symptoms and serum concentrations of homocysteine in men: A population study. Am. J. Clin. Nutr. 2004, 80, 1574-1578. [CrossRef] [PubMed]

152. Tiemeier, T.; van Tuijl, H.R.; Hofman, A.; Meijer, J.; Kiliaan, A.J.; Breteler, M.M. Vitamin B12, folate, and homocysteine in depression: The Rotterdam Study. Am. J. Psychiatry 2002, 159, 2099-2101. [CrossRef] [PubMed]

153. Reynolds, E.H.; Carney, M.W.P.; Toone, B.K. Methylation and Mood. Lancet 1984, 324, 196-198. [CrossRef]

154. Dedoussis, G.V.; Panagiotakos, D.B.; Chrysohoou, C.; Pitsavos, C.; Zampelas, A.; Choumerianou, D.; Stefanadis, C. Effect of interaction between adherence to a Mediterranean diet and the methylenetetrahydrofolate reductase $677 \mathrm{C}->\mathrm{T}$ mutation on homocysteine concentrations in healthy adults: The ATTICA Study. Am. J. Clin. Nutr. 2004, 80, 849-854. [CrossRef]

155. Kim, J.M.; Stewart, R.; Kim, S.W.; Yang, S.J.; Shin, I.S.; Yoon, J.S. Predictive value of folate, vitamin B12 and homocysteine levels in late-life depression. Br. J. Psychiatry 2008, 192, 268-274. [CrossRef]

156. Forti, P.; Rietti, E.; Pisacane, N.; Olivelli, V.; Dalmonte, E.; Mecocci, P.; Ravaglia, G. Blood homocysteine and risk of depression in the elderly. Arch. Gerontol. Geriatr. 2010, 51, 21-25. [CrossRef]

157. Nabi, H.; Bochud, M.; Glaus, J.; Lasserre, A.M.; Waeber, G.; Vollenweider, P.; Preisig, M. Association of serum homocysteine with major depressive disorder: Results from a large population-based study. Psychoneuroendocrinology 2013, 38, 2309-2318. [CrossRef]

158. Papakostas, G.I.; Petersen, T.; Lebowitz, B.D.; Mischoulon, D.; Ryan, J.L.; Nierenberg, A.A.; Bottiglieri, T.; Alpert, J.E.; Rosenbaum, J.F.; Fava, M. The relationship between serum folate, vitamin B12, and homocysteine levels in major depressive disorder and the timing of improvement with fluoxetine. Int. J. Neuropsychopharmacol. 2005, 8, 523-528. [CrossRef]

159. Papakostas, G.I.; Petersen, T.; Mischoulon, D.; Green, C.H.; Nierenberg, A.A.; Bottiglieri, T.; Rosenbaum, J.F.; Alpert, J.E.; Fava, M. Serum folate, vitamin B12, and homocysteine in major depressive disorder, Part 2: Predictors of relapse during the continuation phase of pharmacotherapy. J. Clin. Psychiatry 2004, 65, 1096-1098. [CrossRef] [PubMed] 
160. Papakostas, G.I.; Petersen, T.; Mischoulon, D.; Ryan, J.L.; Nierenberg, A.A.; Bottiglieri, T.; Rosenbaum, J.F.; Alpert, J.E.; Fava, M. Serum folate, vitamin B12, and homocysteine in major depressive disorder, Part 1: Predictors of clinical response in fluoxetine-resistant depression. J. Clin. Psychiatry 2004, 65, 1090-1095. [CrossRef] [PubMed]

161. Papakostas, G.I.; Iosifescu, D.V.; Renshaw, P.F.; Lyoo, I.K.; Lee, H.K.; Alpert, J.E.; Nierenberg, A.A.; Fava, M. Brain MRI white matter hyperintensities and one-carbon cycle metabolism in non-geriatric outpatients with major depressive disorder (Part II). Psychiatry Res. 2005, 140, 301-307. [CrossRef] [PubMed]

162. McMahon, J.A.; Green, T.J.; Skeaff, C.M.; Knight, R.G.; Mann, J.I.; Williams, S.M. A controlled trial of homocysteine lowering and cognitive performance. N. Engl. J. Med. 2006, 354, 2764-2772. [CrossRef]

163. De Koning, E.J.; Zwaluw, N.L.; Wijngaarden, J.P.; Sohl, E.; Brouwer-Brolsma, E.M.; van Marwijk, H.W.; Enneman, A.W.; Swart, K.M.; van Dijk, S.C.; Ham, A.C.; et al. Effects of two-year vitamin B(12) and folic acid supplementation on depressive symptoms and quality of life in older adults with elevated homocysteine concentrations: Additional results from the B-PROOF Study, an RCT. Nutrients 2016, 8, 748. [CrossRef]

164. Schefft, C.; Kilarski, L.L.; Bschor, T.B.; Köhler, S. Efficacy of adding nutritional supplements in unipolar depression: A systematic review and meta-analysis. Eur. Neuropsychopharmacol. 2017, 27, 1090-1109. [CrossRef]

165. Okereke, O.I.; Cook, N.R.; Albert, C.M.; Van Denburgh, M.; Buring, J.E.; Manson, J.E. Effect of long-term supplementation with folic acid and B vitamins on risk of depression in older women. Br. J. Psychiatry 2015, 206, 324-331. [CrossRef]

166. Kwok, T.; Wu, Y.; Lee, J.; Lee, R.; Yung, C.Y.; Choi, G.; Lee, V.; Harrison, J.; Lam, L.; Mok, V. A randomized placebo-controlled trial of using $\mathrm{B}$ vitamins to prevent cognitive decline in older mild cognitive impairment patients. Clin. Nutr. 2019, S0261-5614, 33132. [CrossRef]

167. Mech, A.W.; Farah, A. Correlation of clinical response with homocystein reduction during therapy with reduced B vitamins in patients with MDD who are positive for MTHFR C677T or A1298C polymorphism: A randomized, double-blind, placebo-controlled study. J. Clin. Psychiatry 2016, 77, 668-671. [CrossRef]

168. Coppen, A.; Bailey, J. Enhancement of the antidepressant action of fluoxetine by folic acid: A randomised, placebo controlled trial. J. Affect. Disord. 2000, 60, 121-130. [CrossRef]

169. Papakostas, G.I.; Shelton, R.C.; Zajecka, J.M.; Etemad, B.; Rickels, K.; Clain, A.; Baer, L.; Dalton, E.D.; Sacco, G.R.; Schoenfeld, D.; et al. L-methylfolate as adjunctive therapy for SSRI-resistant major depression: Results of two randomized, double-blind, parallel-sequential trials. Am. J. Psychiatry 2012, 169, 1267-1274. [CrossRef] [PubMed]

170. Resler, G.; Lavie, R.; Campos, J.; Mata, S.; Urbina, M.; García, A.; Apitz, R.; Lima, L. Effect of folic acid combined with fluoxetine in patients with major depression on plasma homocysteine and vitamin B12, and serotonin levels in lymphocytes. Neuroimmunomodulation 2008, 15, 145-152. [CrossRef] [PubMed]

171. Bedson, E.; Bell, D.; Carr, D.; Carter, B.; Hughes, D.; Jorgensen, A.; Lewis, H.; Lloyd, K.; Mccaddon, A.; Moat, S.; et al. Folate Augmentation of Treatment-Evaluation for Depression (FolATED): Randomised trial and economic evaluation. Health Technol. Assess. 2014, 18, 1-159. [CrossRef] [PubMed]

172. Almeida, O.P.; Ford, A.H.; Hirani, V.; Singh, V.; vanBockxmeer, F.M.; McCaul, K.; Flicker, L. B vitamins to enhance treatment response to antidepressants in middle-aged and older adults: Results from the B-VITAGE randomised, double-blind, placebo-controlled trial. Br. J. Psychiatry 2014, 205, 450-457. [CrossRef]

173. Papakostas, G.I.; Shelton, R.C.; Zajecka, J.M.; Bottiglieri, T.; Roffman, J.; Cassiello, C.; Stahl, S.M.; Fava, M. Effect of adjunctive L-methylfolate $15 \mathrm{mg}$ among inadequate responders to SSRIs in depressed patients who were stratified by biomarker levels and genotype: Results from a randomized clinical trial. J. Clin. Psychiatry 2014, 75, 855-863. [CrossRef]

174. Khosravi, M.; Sotoudeh, G.; Amini, M.; Raisi, F.; Mansoori, A.; Hosseinzadeh, M. The relationship between dietary patterns and depression mediated by serum levels of Folate and vitamin B12. BMC Psychiatry 2020, 20, 63. [CrossRef]

175. Assies, J.; Mocking, R.J.T.; Lok, A.; Koeter, M.W.J.; Bockting, C.L.H.; Visser, I.; Pouwer, F.; Ruhé, H.G.; Schene, A.H. Erythrocyte fatty acid profiles and plasma homocysteine, folate and vitamin B6 and B12 in recurrent depression: Implications for co-morbidity with cardiovascular disease. Psychiatry Res. 2015, 229, 992-998. [CrossRef] 
176. Moorthy, D.; Peter, I.; Scott, T.M.; Parnell, L.D.; Lai, C.-Q.; Crott, J.W.; Ordovás, J.M.; Selhub, J.; Griffith, J.; Rosenberg, I.H.; et al. Status of vitamins B-12 and B-6 but not of folate, homocysteine, and the methylenetetrahydrofolate reductase C677T polymorphism are associated with impaired cognition and depression in adults. J. Nutr. 2012, 143, 1554-1560. [CrossRef]

177. Beydoun, M.A.; Shroff, M.R.; Beydoun, H.A.; Zonderman, A.B. Serum folate, vitamin B-12, and homocysteine and their association with depressive symptoms among U.S. adults. Psychosom. Med. 2010, 72, 862-873. [CrossRef]

178. Penninx, B.W.; Guralnik, J.M.; Ferrucci, L.; Fried, L.P.; Allen, R.H.; Stabler, S.P. Vitamin B(12) deficiency and depression in physically disabled older women: Epidemiological evidence from the Women's Health and Aging Study. Am. J. Psychiatry 2000, 157, 715-721. [CrossRef]

179. Elstgeest, L.E.; Brouwer, I.A.; Penninx, B.W.; van Schoor, N.M.; Visser, M. Vitamin B(12), homocysteine and depressive symptoms: A longitudinal study among older adults. Eur. J. Clin. Nutr. 2017, 71, 468-475. [CrossRef] [PubMed]

180. Shivappa, N.; Schoenaker, D.A.; Hebert, J.R.; Mishra, G.D. Association between inflammatory potential of diet and risk of depression in middle-aged women: The Australian Longitudinal Study on Women's Health. Br. J. Nutr. 2016, 116, 1077-1086. [CrossRef]

181. Akbaraly, T.; Kerlau, C.; Wyart, M.; Chevallier, N.; Ndiaye, L.; Shivappa, N.; Hebert, J.R.; Kivimaki, M. Dietary inflammatory index and recurrence of depressive symptoms: Results from the Whitehall II Study. Clin. Psychol. Sci. 2016, 4, 1125-1134. [CrossRef]

182. Sanchez-Villegas, A.; Ruiz-Canela, M.; de la Fuente-Arrillaga, C.; Gea, A.; Shivappa, N.; Hebert, J.R.; Martinez-Gonzalez, M.A. Dietary inflammatory index, cardiometabolic conditions and depression in the Seguimiento Universidad de Navarra cohort study. Br. J. Nutr. 2015, 114, 1471-1479. [CrossRef] [PubMed]

183. Haghighatdoost, F.; Feizi, A.; Esmaillzadeh, A.; Feinle-Bisset, C.; Keshteli, A.H.; Afshar, H.; Adibi, P. Association between the dietary inflammatory index and common mental health disorders profile scores. Clin. Nutr. 2019, 38, 1643-1650. [CrossRef] [PubMed]

184. Imayama, I.; Alfano, C.M.; Kong, A.; Foster-Schubert, K.E.; Bain, C.E.; Xiao, L.; Duggan, C.; Wang, C.-Y.; Campbell, K.L.; Blackburn, G.L.; et al. Dietary weight loss and exercise interventions effects on quality of life in overweight/obese postmenopausal women: A randomized controlled trial. Int. J. Behav. Nutr. Phys. Act. 2011, 8, 118. [CrossRef]

185. Molendijk, M.L.; Fried, E.I.; Van der Does, W. The SMILES trial: Do undisclosed recruitment practices explain the remarkably large effect? BMC Med. 2018, 16, 243. [CrossRef]

186. Horton, R. Expression of concern: Indo-Mediterranean Diet Heart Study. Lancet 2005, 366, 354-356. [CrossRef]

187. Bloch, M.H.; Hannestad, J. Omega-3 fatty acids for the treatment of depression: Systematic review and meta-analysis. Mol. Psychiatry 2012, 17, 1272-1282. [CrossRef]

188. Vermetten, E.; Bremner, J.D. Circuits and systems in stress. I. Preclinical studies. Depress. Anxiety 2002, 15, 126-147. [CrossRef]

189. Charney, D.S.; Bremner, J.D. The neurobiology of anxiety disorders. In Neurobiology of Mental Illness; Charney, D.S., Nestler, E.J., Bunney, S.S., Eds.; Oxford University Press: Oxford, UK, 1999; pp. 494-517.

190. Inoue, T.; Tsuchiya, K.; Koyama, T. Regional changes in dopamine and serotonin activation with various intensity of physical and psychological stress in the rat brain. Pharmacol. Biochem. Behav. 1994, 49, 911-920. [CrossRef]

191. Petty, F.; Kramer, G.L.; Wu, J. Serotonergic modulation of learned helplessness. Ann. N. Y. Acad. Sci. 1997, 821, 538-541. [CrossRef] [PubMed]

192. Vermetten, E.; Bremner, J.D. Circuits and systems in stress. II. Applications to neurobiology and treatment of PTSD. Depress. Anxiety 2002, 16, 14-38. [CrossRef] [PubMed]

193. Southwick, S.M.; Krystal, J.H.; Bremner, J.D.; Morgan, C.A.; Nicolaou, A.; Nagy, L.M.; Johnson, D.R.; Heninger, G.R.; Charney, D.S. Noradrenergic and serotonergic function in posttraumatic stress disorder. Arch. Gen. Psychiatry 1997, 54, 749-758. [CrossRef]

194. Yehuda, R. Post-traumatic stress disorder. N. Engl. J. Med. 2002, 346, 108-114. [CrossRef]

195. Bremner, J.D.; Krystal, J.H.; Southwick, S.M.; Charney, D.S. Noradrenergic mechanisms in stress and anxiety: I. Preclinical studies. Synapse 1996, 23, 28-38. [CrossRef]

196. Bremner, J.D.; Krystal, J.H.; Southwick, S.M.; Charney, D.S. Noradrenergic mechanisms in stress and anxiety: II. Clinical studies. Synapse 1996, 23, 39-51. [CrossRef] 
197. Abercrombie, E.D.; Jacobs, B.L. Single-unit response of noradrenergic neurons in the locus coeruleus of freely moving cats. I. Acutely presented stressful and non-stressful stimuli. J. Neurosci. 1987, 7, 2837-2847. [CrossRef]

198. Abercrombie, E.D.; Jacobs, B.L. Single-unit response of noradrenergic neurons in the locus coeruleus of freely moving cats. II. Adaptation to chronically presented stressful stimuli. J. Neurosci. 1987, 7, 2844-2848. [CrossRef]

199. Foote, S.L.; Bloom, F.E.; Aston-Jones, G. Nucleus locus coeruleus: New evidence of anatomical and physiological specificity. Physiol. Behav. 1983, 63, 844-914.

200. Levine, E.S.; Litto, W.J.; Jacobs, B.L. Activity of cat locus coeruleus noradrenergic neurons during the defense reaction. Brain Res. 1990, 531, 189-195. [CrossRef]

201. Redmond, D.; Huang, Y. New evidence for a locus coeruleus-norepinephrine connection with anxiety. Life Sci. 1979, 25, 2149-2162. [CrossRef]

202. Jedema, H.P.; Finlay, J.M.; Sved, A.F.; Grace, A.A. Chronic cold exposure potentiates CRH-evoked increases in electrophysiologic activity of locus coeruleus neurons. Biol. Psychiatry 2001, 49, 351-359. [CrossRef]

203. Nisenbaum, L.K.; Abercrombie, E.D. Presynaptic alterations associated with enhancement of evoked release and synthesis of NE in hippocampus of chemically cold stressed rats. Brain Res. 1993, 608, 280-287. [CrossRef]

204. Aston-Jones, G.; Shipley, M.T.; Chouvet, G.; Ennis, M.; VanBockstaele, E.J.; Pieribone, V.; Shiekhattar, R. Afferent regulation of locus coeruleus neurons: Anatomy, physiology and pharmacology. Prog. Brain Res. 1991, 88, 47-75.

205. Southwick, S.M.; Krystal, J.H.; Morgan, C.A.; Johnson, D.; Nagy, L.M.; Nicolaou, A.; Heninger, G.R.; Charney, D.S. Abnormal noradrenergic function in posttraumatic stress disorder. Arch. Gen. Psychiatry 1993, 50, 266-274. [CrossRef]

206. Bremner, J.D.; Innis, R.B.; Ng, C.K.; Staib, L.; Duncan, J.; Bronen, R.; Zubal, G.; Rich, D.; Krystal, J.H.; Dey, H.; et al. PET measurement of cerebral metabolic correlates of yohimbine administration in posttraumatic stress disorder. Arch. Gen. Psychiatry 1997, 54, 246-256. [CrossRef]

207. Rossi, J.; Zolovick, A.J.; Davies, R.F.; Panksepp, J. The role of norepinephrine in feeding behavior. Neurosci. Biobehav. Rev. 1982, 6, 195-204. [CrossRef]

208. Wise, R.A. Role of brain dopamine in food reward and reinforcement. Philos. Trans. R. Soc. Lond. Ser. B Biol. Sci. 2006, 361, 1149-1158. [CrossRef]

209. Bremner, J.D.; Pearce, B. Neurotransmitter, neurohormonal, and neuropeptidal function in stress and PTSD. In Posttraumatic Stress Disorder: From Neurobiology to Treatment; Bremner, J.D., Ed.; Wiley-Blackwell: Hoboken, NJ, USA, 2016; pp. 181-232.

210. Kalivas, P.W.; Abhold, R. Enkephalin release in to the ventral tegmental area in response to stress: Modulation of mesocortical dopamine. Biol. Psychiatry 1987, 414, 339-348. [CrossRef]

211. Krisch, B. Somatostatin-immunoreactive fiber projections into the brain stem and the spinal cord of the rat. Cell Tissue Res. 1981, 217, 531-552. [CrossRef] [PubMed]

212. Vecsei, L.; Kiraly, C.; Bollok, I.; Nagy, A.; Varga, J.; Penke, B.; Telegdy, G. Comparative studies with somatostatin and cysteamine in different behavioral tests on rats. Pharmacol. Biochem. Behav. 1984, 21, 833-837. [CrossRef]

213. Benyassi, A.; Gavalda, A.; Armario, A.; Arancibia, S. Role of somatostatin in the acute immobilization stress-induced GH decrease in rat. Life Sci. 1993, 52, 361-370. [CrossRef]

214. Bremner, J.D.; Licinio, J.; Darnell, A.; Krystal, J.H.; Owens, M.; Southwick, S.M.; Nemeroff, C.B.; Charney, D.S. Elevated CSF corticotropin-releasing factor concentrations in posttraumatic stress disorder. Am. J. Psychiatry 1997, 154, 624-629.

215. Weiss, J.M.; Bonsall, R.W.; Demetrikopoulos, M.K.; Emery, M.S.; West, C.H.K. Galanin: A significant role in depression? Ann. N. Y. Acad. Sci. 1998, 863, 364-384. [CrossRef]

216. Karlsson, R.M.; Holmes, A. Galanin as a modulator of anxiety and depression and a therapeutic target for affective disease. Amino Acids 2006, 31, 231-239. [CrossRef]

217. Yildiz, B.O.; Suchard, M.A.; Wong, M.L.; McCann, S.M.; Licinio, J. Alterations in the dynamics of circulating ghrelin, adiponectin, and leptin in human obesity. Proc. Natl. Acad. Sci. USA 2004, 101, 10434-10439. [CrossRef]

218. Stengel, A.; Wang, L.; Tache, Y. Stress-related alterations of acyl and desacyl ghrelin circulating levels: Mechanisms and functional implications. Peptides 2011, 32, 2208-2217. [CrossRef] 
219. Spencer, S.J.; Xu, L.; Clarke, M.A.; Lemus, M.; Reichenbach, A.; Geenen, B.; Kozicz, T.; Andrews, Z.B. Ghrelin regulates the hypothalamic-pituitary-adrenal axis and restricts anxiety after acute stress. Biol. Psychiatry 2012, 72, 457-465. [CrossRef]

220. Chuang, J.C.; Perello, M.; Sakata, I.; Osborne-Lawrence, S.; Savitt, J.M.; Lutter, M.; Zigman, J.M. Ghrelin mediates stress-induced food-reward behavior in mice. J. Clin. Investig. 2011, 121, 2684-2692. [CrossRef]

221. Meyer, R.M.; Burgos-Robles, A.; Liu, E.; Correia, S.S.; Goosens, K.A. A ghrelin-growth hormone axis drives stress-induced vulnerability to enhanced fear. Mol. Psychiatry 2014, 19, 1284-1294. [CrossRef] [PubMed]

222. Bailey, M.T.; Dowd, S.E.; Galley, J.D.; Hufnagle, A.R.; Allen, R.G.; Lyte, M. Exposure to a social stressor alters the structure of the intestinal microbiota: Implications for stressor-induced immunomodulation. Brain. Behav. Immun. 2011, 25, 397-407. [CrossRef] [PubMed]

223. Bercik, P.; Denou, E.; Collins, J.; Jackson, W.; Lu, J.; Jury, J.; Deng, Y.; Blennerhassett, P.; Macri, J.; McCoy, K.D.; et al. The intestinal microbiota affect central levels of brain-derived neurotropic factor and behavior in mice. Gastroenterology 2011, 141, 599-609. [CrossRef] [PubMed]

224. Bravo, J.A.; Forsythe, P.; Chew, M.V.; Escaravage, E.; Savignac, H.M.; Dinan, T.G.; Bienenstock, J.; Cryan, J.F. Ingestion of Lactobacillus strain regulates emotional behavior and central GABA receptor expression in a mouse via the vagus nerve. Proc. Natl. Acad. Sci. USA 2011, 108, 16050-16055. [CrossRef]

225. Cani, P.D.; Everard, A. Talking microbes: When gut bacteria interact with diet and host organs. Mol. Nutr. Food Res. 2016, 60, 58-66. [CrossRef]

226. Collins, S.M.; Surette, M.; Bercik, P. The interplay between the intestinal microbes and the brain. Nat. Rev. Microbiol. 2012, 10, 735-742. [CrossRef]

227. De Lartigue, G.; Barbier de La Serre, C.; Raybould, H.E. Vagal afferents in high gat diet-induced obesity: Intestinal microflora, gut inflammation and cholecystokinin. Physiol. Behav. 2011, 105, 100-105. [CrossRef]

228. Dinan, T.G.; Cryan, J.F. Melancholic microbes: A link between gut microbiota and depression? Neurogastroenterol. Motil. 2013, 25, 713-719. [CrossRef]

229. Dinan, T.G.; Stanton, C.; Cryan, J.F. Psychobiotics: A novel class of psychotropic. Biol. Psychiatry 2013, 74, 720-726. [CrossRef]

230. Valles-Colomer, M.; Falony, G.; Darzi, Y.; Tigchelaar, E.F.; Wang, J.; Tito, R.Y.; Schiweck, C.; Kurilshikov, A.; Joossens, M.; Wijmenga, C.; et al. The neuroactive potential of the gut microbiota in quality of life and depression. Nat. Microbiol. 2019, 4, 623-632. [CrossRef]

231. Tillisch, K.; Labus, J.; Kilpatrick, L.; Jiang, Z.; Stains, J.; Ebrat, B.; Guyonnet, D.; Legrain-Raspaud, S.; Trotin, B.; Naliboff, B.; et al. Consumption of fermented milk product with probiotic modulates brain activity. Gastroenterology 2013, 144, 1394-1401. [CrossRef] [PubMed]

232. Blumenthal, J.A.; Bayak, M.A.; Moore, K.A. Effects of exercise training on older patients with major depression. Arch. Intern. Med. 1999, 159, 2349-2356. [CrossRef] [PubMed]

(C) 2020 by the authors. Licensee MDPI, Basel, Switzerland. This article is an open access article distributed under the terms and conditions of the Creative Commons Attribution (CC BY) license (http://creativecommons.org/licenses/by/4.0/). 